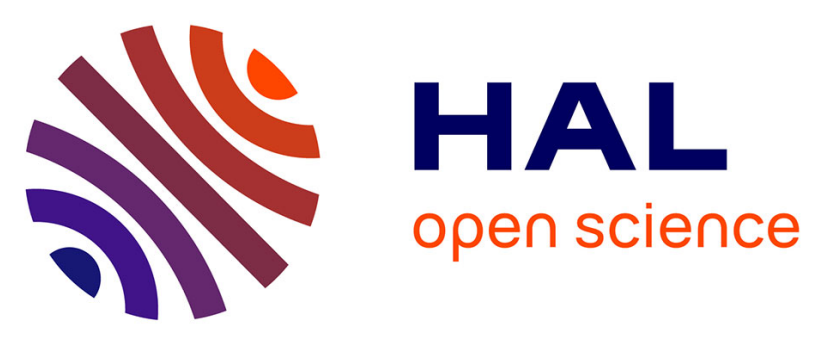

\title{
Impact of gneissic layering and localized incipient melting upon melt flow during experimental deformation of migmatites
}

Anne-Céline Ganzhorn, Pierre Trap, Laurent Arbaret, Rémi Champallier, Julien Fauconnier, Loic Labrousse, Gaëlle Prouteau

\section{To cite this version:}

Anne-Céline Ganzhorn, Pierre Trap, Laurent Arbaret, Rémi Champallier, Julien Fauconnier, et al.. Impact of gneissic layering and localized incipient melting upon melt flow during experimental deformation of migmatites. Journal of Structural Geology, 2016, 85, pp.68-84. 10.1016/j.jsg.2016.02.004 . insu-01275193

\section{HAL Id: insu-01275193 \\ https://hal-insu.archives-ouvertes.fr/insu-01275193}

Submitted on 17 Feb 2016

HAL is a multi-disciplinary open access archive for the deposit and dissemination of scientific research documents, whether they are published or not. The documents may come from teaching and research institutions in France or abroad, or from public or private research centers.
L'archive ouverte pluridisciplinaire HAL, est destinée au dépôt et à la diffusion de documents scientifiques de niveau recherche, publiés ou non, émanant des établissements d'enseignement et de recherche français ou étrangers, des laboratoires publics ou privés.

\section{(ㅇ)(1) $\$$}

Distributed under a Creative Commons Attribution - NonCommercial - NoDerivatives 44.0 
Highlights :

- Purpose: examine experimentally control of anisotropies on melt flow in migmatites.

- Experiments on a homogeneous gneiss and one with strong mineral layering.

- Initial anisotropy strongly controls melt flow and segregation at sample-scale.

- Initial anisotropy also controls deformation distribution and its partitioning.

- Boudinage occurs in the gneiss with mineral layering. 
1 Title: Impact of gneissic layering and localized incipient melting upon melt flow during

2 experimental deformation of migmatites

3

4 Ganzhorn A.C.* $*_{a, b, c, d}$, Trap P.e, Arbaret L.b.c.d., Champallier R.b.c.d., Fauconnier J.a, Labrousse

$5 \quad$ L.a and Prouteau G.b.c.d.

6

7 a Sorbonne Universités, UPMC Univ Paris 06, CNRS, Institut des Sciences de la Terre de

8 Paris (iSTeP), 4 place Jussieu 75005 Paris, France

9 b Univ. d'Orléans, UMR 7327, ISTO, F-45071 ORLEANS.

10 c CNRS/INSU, UMR 7327, ISTO, F-45071 ORLEANS.

11 d BRGM, ISTO, UMR 7327, F-45071 ORLEANS.

12 e Université de Franche Comté, UMR 6249, Laboratoire Chrono-environnement, F-25030

13 BESANCON.

14

$15 \quad$ anneceline.ganzhorn@gmail.com +33(0)1 44274904

16 pierre.trap@univ-fcomte.fr

$17 \quad \underline{\text { Laurent.arbaret@univ-orleans.fr }}$

18 remi.champallier@cnrs-orleans.fr

19 julien.fauconnier@upmc.fr

20 loic.labrousse@upmc.fr

21 gaelle.prouteau@cnrs-orleans.fr

23 Keywords: anisotropy, natural gneiss, pure-shear deformation, partially molten 
Abstract:

In this study, we test experimentally the role of compositional layering as a key parameter for controlling melt flow in a natural migmatite during coaxial deformation. We performed in situ pure-shear experiments on two natural gneisses. The first gneiss is weakly foliated with minerals homogenously distributed. The second gneiss shows a pronounced compositional layering of alternating quartz - feldspar - rich and biotite - muscovite - rich layers. Experimental conditions were selected to obtain homogeneous melt distribution in the homogeneous gneiss and heterogeneous melt distribution in the layered gneiss. Initial melt distribution is not modified by deformation in experiments on the homogeneous gneiss, implying that melting products did not migrate from their initiation sites. In contrast, melt flowed in shear zones or in inter-boudin positions during experimental deformation of the heterogeneous gneiss. These experiments attest to the strong influence of initial gneissic layering on melting pattern, melt segregation and flow during deformation of partially molten rocks.

\section{Introduction}

Within the crust, partial melting is the main geological process responsible for production of leucogranites, crustal differentiation (Rudnick, 1995) and major changes in crustal strength (Rosenberg \& Handy, 2005). Field evidence shows that exhumation of highpressure metamorphic rocks or extrusion of large tectonic slices are facilitated when the crust reaches its solidus (e.g. Labrousse et al., 2011; Trap et al., 2011). Magneto-telluric (Hashim et al., 2013) and seismic (Nelson et al., 1996) surveys in the North-West Himalaya seem to confirm the presence of a partially molten crust at depth, which are responsible for large-scale lateral flow of the Eurasian crust (Caldwell et al., 2009). At smaller scale, many field observations within migmatitic terrains emphasize the feedback relationship between crustal 
weakening and the production, segregation and flow of silicate melt (e.g. Brown \& Solar, 1998).

Melt fraction is documented as the first parameter controlling mechanical behaviour and localization of deformation of partially molten aggregates in experimental studies (e.g. Misra et al., 2009). Melt fraction is inferred to have a drastic weakening effect on bulk rock strength (Arzi, 1978; Van der Molen \& Paterson, 1979; Rutter et al., 2006). Rosenberg \& Handy (2005) showed that $10 \%$ partial melting of a dry aplite leads to a strength drop from $820 \mathrm{MPa}$ down to $80 \mathrm{MPa}$ in experimental conditions. This first order of magnitude in strength drop is expected to represent a two orders of magnitude drop in effective viscosity for bulk non-Newtonian behaviour with stress exponent $n=3$.

Melt viscosity also influences the rheological behaviour of partially molten rocks. It depends mostly on melt silica and water contents, as well as temperature. The addition of 1 wt $\% \mathrm{H}_{2} \mathrm{O}$ to a dry haplogranite at $800^{\circ} \mathrm{C}$ can induce a viscosity drop from $10^{13} \mathrm{~Pa}$.s to $10^{7}$ Pa.s (Dingwell et al., 1996). Similarly, hydrated melts (1 wt $\% \mathrm{H}_{2} \mathrm{O}$ and above) maintain substantially equivalent low viscosities (between $10^{6}$ and $10^{7} \mathrm{~Pa} . \mathrm{s}$ ). In contrast, at similar conditions, an increase of $100^{\circ} \mathrm{C}$ in melt temperature, which represents the actual variation tested in our experiments, induces less than a one-order viscosity drop for hydrated haplogranite melts (Dingwell et al., 1996).

Melt distribution is also a major parameter that controls rock strength, responsible for local changes on melt percentage. In particular, a strength drop occurs for a $10 \%$ melt fraction when full connectivity of melt pockets is achieved in experiments (Rosenberg \& Handy, 2005). Grain-scale surface energy (Cooper \& Kohlstedt, 1984; Laporte \& Watson, 1995), differential stress (Daines \& Kohlstedt, 1997; Zimmerman et al., 1999) and finite deformation magnitude (Kohlstedt \& Zimmerman, 1996) have been recognized as controlling parameters for melt distribution. In addition, Tumarkina et al. (2011) argued that protolith anisotropy, in 
particular foliation orientation, is critical for partial melting rate. Yet, anisotropy seems to have little impact on rheological behaviour of partially molten rocks although it may influence their behaviour in sub-solidus domains (Holyoke \& Rushmer, 2002). According to Marchildon \& Brown (2003) the distribution of leucosomes within migmatites is controlled by protolith anisotropy rather than by regional stresses. With prograde metamorphism, incipient partial melting leads to the formation of metatexites where paleosome dominates. Metatexites are typically heterogeneous with leucosomes (crystallized melt) arranged in a planar manner and oriented parallel to the protolith planar anisotropy, i.e. compositional/gneissic layering (Marchildon \& Brown, 2003; Sawyer, 2008). Thus, inherited protolith planar fabric and related melt distribution after incipient melting may be an important parameter to consider when studying strength of partially molten continental crust and related melt flow.

In this contribution, we test the impact of incipient melt distribution as a function of host rock texture (isotropic vs anisotropic) for the deformation of partially molten rocks (migmatites) and melt flow. Two sets of pure-shear experiments were performed on two natural gneisses using a Paterson apparatus. We focus on natural gneisses to avoid artificial porosity, potentially high in synthetic material (up to 15\%; Misra et al., 2014) that may disturb melt distribution. One natural gneiss shows a pronounced gneissic layering whereas the other is compositionally homogeneous, so that we could document changes in melt distribution as a function of the fabric of the starting gneiss for an experiment. In addition, incipient melt distribution, homogenous $v s$ heterogeneous, was controlled using different experimental conditions, i.e. temperature and hydration, to promote water - present and muscovite - dehydration melting reactions and prevent other melting reactions, in particular, biotite - dehydration melting. Homogeneous gneiss was deformed at relatively low temperature $\left(850^{\circ} \mathrm{C}\right.$ and below), in hydrated and dry conditions, while heterogeneous gneiss 
was experimented at higher temperature $\left(850^{\circ} \mathrm{C}\right.$ and above) and dry conditions. One experiment set-up $\left(850^{\circ} \mathrm{C}\right.$, dry conditions) is common to both experiment series. The comparison of deformation patterns and melt distributions observed in our experiments allow to discuss the impact of the inherited gneissic layering and related melt distribution on melt flow and deformation of partially molten rocks.

\section{Starting materials}

Starting materials are two natural gneisses, one homogeneous, weakly foliated gneiss (NOP1) with no compositional layering and one heterogeneous gneiss (PX28) with a strong gneissic layering (Fig. 1). For both starting materials, we also choose experimental conditions to restrain melt production to water - present and to muscovite - dehydration melting reactions, and prevent biotite - dehydration melting. This approach required to adjust experimental conditions using different temperatures with addition of free water for some experiments. The experimental set up were designed to work with two texturally different migmatites, one with a homogenous distribution of melt (in NOP1) and one with a layeredtype distribution of melt (in PX28).

\subsection{Homogeneous gneiss: sample NOP1}

The homogeneous gneiss (NOP1) is a quartzo-feldspathic two - mica gneiss, sampled in the inland of the Western Gneiss Region in Norway (N62 05'29' E006 51'976', UTM32). Modal composition is $45 \%$ quartz, $20 \%$ muscovite, $20 \%$ biotite, and $15 \%$ plagioclase. Accessory minerals are Fe-Ti oxides and zircons. Minerals are homogeneously distributed at sample scale with a weak foliation marked by preferred orientation of micas and elongated quartz grains and aggregates (Fig. 1a). The typical rock fabric is made of $1 \mathrm{~mm}$ thick and up to $5 \mathrm{~mm}$ long quartz aggregates (composed of grains with maximum length 
124 about $500 \mu \mathrm{m}$ to $1 \mathrm{~mm}$ ) surrounded by grains of micas and plagioclase of ca. $100 \mu \mathrm{m}$ in size

125 and even locally smaller (Fig. 1b).

126 'Insert figure 1 here'

127 Melting tests on the homogeneous gneiss (NOP1) revealed that partial melting does not occur

128 for $\mathrm{T}<825^{\circ} \mathrm{C}$ probably due to paucity of free water. Melting through the biotite - dehydration

129 reaction started for $\mathrm{T}=850^{\circ} \mathrm{C}$. To avoid biotite melting and to promote melting through water

130 - present reactions and homogenous distribution of melt, the starting material was hydrated

131 prior to the deformation experiments. With the addition of free $\mathrm{H}_{2} \mathrm{O}$, experiments were run at

132 temperature of $750^{\circ} \mathrm{C}$ to avoid biotite - related melting.

133 Hydration was performed at room pressure and temperature during three days in a closed

134 glass containing distilled water. Complete and homogeneous hydration is only attained for

135 small core sizes (diameter $=5 \mathrm{~mm}$ ). To enhance hydration, cores were plunged into distilled

136 water and placed in a vacuum holder one hour per day. Hydrated cores were sealed within

137 gold caps and heated at $750^{\circ} \mathrm{C}, 300 \mathrm{MPa}$ for 48 hours in an internal-heated vessel. In that

138 way, water was dissolved and trapped in the melt, which became hydrated glass when cores

139 were quenched. This hydrated homogeneous gneiss is sample NOP1-B whereas the dry

140 homogenous gneiss is sample NOP1-A (Table 1).

141 'Insert Table 1'

142

$143 \quad 2.2$ Heterogeneous gneiss: sample PX28

144 Starting material PX28 is a quartzo-feldspathic two - mica gneiss, sampled in the

145 Sioule Valley in the French Massif Central (46.110613, 3.013235). Modal composition is

$14650 \%$ quartz, 20\% feldspars with mainly plagioclase and little K-feldspar, $20 \%$ biotite and

$14710 \%$ muscovite. Accessory minerals are zircon, apatite, and monazite. PX28 is well foliated 
148 and shows a pronounced gneissic layering defined by millimetre - thick mica - rich and

149 quartz - rich layers (Fig. 1c). Within leucocratic layers, quartz and feldspars display a 50-100 $150 \mu \mathrm{m}$ grain size, with elongated biotite and few muscovite grains up to $100 \mu \mathrm{m}$ long and $20 \mu \mathrm{m}$

151 thick. In mica-rich layers, biotites and muscovites are commonly 100-500 $\mu \mathrm{m}$ long and 10-50

$152 \mu \mathrm{m}$ thick and reach up to $1 \mathrm{~mm}$ long and $1 \mathrm{~mm}$ thick, with some very rare grains up to $3 \mathrm{~mm}$

153 in length. Muscovite grains are preferentially located within mica - rich layers and represent

154 less than $1 \%$ of quartzo-feldspathic layers volume. Within mica - rich layers, foliation is 155 locally deflected by $100 \mu \mathrm{m}$ to $1 \mathrm{~mm}$ thick shear zones (Fig. 1d) marked by mica deflections.

156 Within shear zones, some small 10-50 $\mu \mathrm{m}$-size quartz and feldspar grains occur. One 157 experiment under hydrostatic conditions, i.e. without deformation, (PP123: $850^{\circ} \mathrm{C}, 300 \mathrm{MPa}$, 1581 h45 min; Table 1) was performed. Only slight modifications of PX28 fabric were observed

159 with quartz-feldspar grain boundaries becoming more rounded and production of melt. Within 160 shear zones, small grains became uncommon, which we attribute to melt consumption.

161 Deformation experiments were therefore preceded by a 30 minutes heating event under 162 hydrostatic conditions at running temperature so as to limit the influence of small - scale 163 structures and grain - size heterogeneities on melt generation and migration.

\section{Experimental methods}

Pure-shear deformation experiments were performed in an internally heated gas-

167 medium deformation apparatus (Paterson instrument, Australian Scientific Instrument) at 168 ISTO Orléans, France. Cylinders with 5 to $15 \mathrm{~mm}$ in diameter and 10.3 to $28.8 \mathrm{~mm}$ in length 169 (Table 1) are cored perpendicularly to the initial foliation for both natural gneisses. The

170 smallest diameter is used for experiments on the homogeneous gneiss NOP1 with water added 171 (starting material NOP1-B in Table 1) since complete hydration of a sample could only be 172 completed for the small - diameter cores. Length of cores depends on the fragility of the 
material and/or the cylinder; as for example long cores with smallest diameter were difficult

174 to drill. Although cores of both gneisses have different mineral sizes and different diameters

175 of cylinder were used, a minimum of 30 grains could always be traversed across the core so

176 that individual large grains do not affect the mechanical behaviour of the entire samples.

177 Opposite faces of cylinders were finely polished to achieve parallelism within $\pm 3 \mu \mathrm{m}$. Cores

178 were then inserted in a column assembly made of alumina and zirconia pistons enclosed in an

179 iron jacket (Champallier et al., 2008). To limit loss of fluid and isolate the sample from the

180 thermocouple, two $3 \mathrm{~mm}$-thick alumina spacers were inserted between the rock sample and

181 alumina pistons. Two geometries of column are used depending on core size. For the smallest

182 cores (diameter $=5 \mathrm{~mm}$ ), a copper cylinder was introduced between the sample and the iron

183 jacket in order to fill the gap between them (cores: diameter $=5 \mathrm{~mm}$, iron jacket: diameter $=$

$18410 \mathrm{~mm}$ ). The diameter of the iron jacket was reduced to $10 \mathrm{~mm}$ at sample edges, forming "dog-bone" geometry. For bigger cores, no reduction was needed since core diameter equals internal iron jacket diameter. A platinum foil $(25 \mu \mathrm{m})$ was systematically introduced between core and iron jacket to prevent any chemical reaction between melt and iron. The column was

188 placed in the Paterson apparatus to locate the sample in the isothermal zone of the heating 189 chamber (temperature controlled at $\pm 1^{\circ} \mathrm{C}$ over a distance of $5 \mathrm{~cm}$ ). Temperature was measured with a K-type thermocouple situated at $3 \mathrm{~mm}$ from the top of the sample. Argon was used as confining medium. Force was applied with a motor located below the column

192 assembly, where the top of the column assembly being fixed. Force was monitored by an 193 internal load cell with a $10 \mathrm{~N}$ resolution (Champallier, 2005). Experiments were performed at 194 a constant $300 \mathrm{MPa}$ confining pressure, at different temperatures $\left(750^{\circ} \mathrm{C}, 850^{\circ} \mathrm{C}\right.$ and $\left.900^{\circ} \mathrm{C}\right)$ 195 and strain rates varying from $10^{-5} \mathrm{~s}^{-1}$ to $1.25^{*} 10^{-3} \mathrm{~s}^{-1}$. Experiment names are based on (1) type 196 of material, (2) temperature $\left({ }^{\circ} \mathrm{C}\right)$ and (3) glass content (surfacic \%). For the homogeneous 197 gneiss (NOP1), experiments names start with "Ho" (Table 1). For the heterogeneous gneiss 
198 (PX28), experiments names start with "He". For example, Ho/750/6 corresponds to the 199 experiment performed on the homogeneous gneiss (NOP1) at $750^{\circ} \mathrm{C}$ with a glass content of 6\%. Strain rate is kept constant over the whole duration of the Ho/750/6 experiment. Ho/850/33, He/850/19 \& He/900/21-32 experiments experienced several strain rate steps. Details about experimental conditions are summarized in Table 1. Deformation began after temperature and pressure equilibrium was reached, meaning that melting reactions or glass-tomelt transformation began before deformation. Thus, deformation started in presence of melt.

The deformed cores were cut along the long axis, i.e. perpendicular to the protolith foliation. Thin sections were observed under polarized microscope and SEM. Glass amount after deformation was estimated from representative zones for each core (compilation of 4 to 15 SEM images). Given that glass and plagioclase have similar grey colour in SEM images, which prevented automated calculation of glass amount. Glass location was optically 210 observed and manually drawn for each SEM image. To better resolve local glass (former 211 melt) distribution, chemical maps are also acquired at several locations for two representative 212 experiments (Ho/850/33 \& He/900/21-32, see section 4.5). From the combination of elemental maps, mineral phases are recognized by automatic clustering using "k-means" 214 algorithm. One pixel of each phase was manually picked as initial guess to ensure proper 215 convergence of the algorithm. The algorithm then assigns a phase to each pixel based on his 216 statistical similarity with those initial guess. Then pixels recognized as glass are counted to 217 calculate glass amount. Comparisons between manual and automatic estimations of glass 218 amount, on the same area, are in good agreement (e.g. for the zone represented in Fig. 11b: $22 \%$ obtained from manually drawn and $20 \%$ from computation).

221 (Intercept2003 and SPO2003 software, Launeau \& Robin, 1996; Launeau et al., 2010), to 222 determine the statistical long-axis orientation of glass pockets and the amount (surfacic \%) of 
223

glass. Shear zones were optically recognized and shear zone geometry was drawn. Then shear zone orientations were measured in the same way than glass (former melt) pockets.

For each protolith, two experiments were performed at two different temperatures to achieve conditions with low and high melt fractions. Different strain rates varying from $10^{-5} \mathrm{~s}^{-}$ ${ }^{1}$ to $1.25^{*} 10^{-3} \mathrm{~s}^{-1}$ were tested, depending on the mechanical response of the sample during an experiment.

\section{Experimental results}

\subsection{Partial melting reactions in both protoliths}

In non - deformed hydrated cores from the homogeneous gneiss NOP1 (after the passage in an internal-heated vessel), glass is observed around muscovite grains in contact with quartz (Fig. 2a) and contains small euhedral newly formed biotite and sillimanite. Rare spinel and corundum are sometimes observed. These microcrystalline phases are systematically oriented and do not show any typical quenching textures (disoriented acicular growth pattern for instance). We therefore consider them as melting reaction products together with the melt represented by the interstitial glass after quenching (Webb \& Knoche, 1996). We interpret the presence of glass, biotite and sillimanite, between muscovite and quartz, as indicating the water - present partial melting reaction documented in metapelitic system (Clemens \& Vielzeuf, 1987; Solar \& Brown, 2001):

$$
\mathrm{Ms}+\mathrm{Qtz}+\mathrm{Pl}+\mathrm{H}_{2} \mathrm{O}=\mathrm{Melt} 1+\mathrm{Bt}+\mathrm{Sill}
$$

abbreviations after Kretz (1983). Spinel may be the product of the biotite - dehydration reaction:

$$
\text { Sill }+\mathrm{Bi}+\mathrm{Pl}=\mathrm{Sp}+\text { Melt }
$$


with sillimanite as a product of reaction (1). In the KFMASH system (rock chemistry reduced

to $\mathrm{K}, \mathrm{Fe}, \mathrm{Mg}, \mathrm{Al}, \mathrm{Si}$ and $\mathrm{H}$ a simplification relevant for quartzo-feldspathic rocks; Spear \&

248 Cheney, 1989), spinel and corundum may result from the reaction:

$$
\mathrm{Bt}+\mathrm{Sill}=\mathrm{Grt}+\mathrm{Sp}+\mathrm{Cr}+\text { Melt }
$$

In cores of NOP1-B, glass without any associated newly formed peritectic phase is also abundant between plagioclase and quartz (same geometry than in Fig. 2b), indicating the former presence of melt and thus the following water - present partial melting reaction (Boettcher and Wyllie, 1969):

$$
\mathrm{Pl}+\mathrm{Qtz}+\mathrm{H}_{2} \mathrm{O}=\mathrm{Melt} 2
$$

In cores from the heterogeneous gneiss PX28 and from non-modified homogeneous gneiss NOP1 (NOP1-A in Table 1), the same glass and newly formed peritectic phases association as in hydrostatic test experiments (e.g. PP123, Table 1) are observed. We therefore interpret them as produced during the initial hydrostatic stage of the deformation experiment. Glass is present around muscovite grains and along muscovite cleavages, indicating the presence of former melt in contact of muscovite and quartz (Fig. 2c). Glass is associated with newly formed peritectic grains (micrometric crystals with needle or prismatic shape) of biotite, sillimanite and K-feldspar (Figs. 2c \& d), indicating the following dehydration partial melting reaction (Patiño Douce \& Harris, 1998; Castro et al., 2000):

$$
\mathrm{Ms}+\mathrm{Pl}+\mathrm{Qtz}=\mathrm{Melt} 3+\mathrm{Kfsp}+\mathrm{Sill}+\mathrm{Bt}
$$

265 Glass without newly formed peritectic phases is also observed at plagioclase-quartz grain 266 boundaries (Fig. 2b). Considering that temperatures and pressure used in those experiments $\left(850^{\circ} \mathrm{C}\right.$ in $\mathrm{He} / 850 / 19$ and $900^{\circ} \mathrm{C}$ in $\mathrm{He} / 900 / 21-32$, both at $\left.300 \mathrm{MPa}\right)$ are too low for water absent partial melting of Plg+Qtz to occur (reaction reached at $900^{\circ} \mathrm{C}$ for similar pressure, 
270 direct product of water - present partial melting (melt2 in reaction 4) or after interaction 271 between melt (melt3 formed by reaction 5) and plagioclase following the reaction:

$$
\text { Melt3+Plg } \pm \text { Qtz=Melt4 }
$$

For both protoliths, biotite also shows isolated glass pockets along cleavages (Fig. 2d).

274 This occurrence may indicate either sporadic hydrated partial melting of the biotite or 275 incipient destabilization of biotite within a former melt that was produced by reaction (1), (4) 276 or $(5)$

'Insert figure 2 here'

\subsection{Mechanical data}

\subsubsection{The homogeneous gneiss NOP1}

The two experiments on the homogeneous gneiss NOP1 were performed in different manners: experiment Ho/750/6 was performed for one single strain rate value, whereas experiment $\mathrm{Ho} / 850 / 33$ is the succession of four strain-rate steps, with an increase of strain rate at each step. Even if protocols were different, it is possible to draw first order comparison of stress evolution with strain between $\mathrm{Ho} / 750 / 6$ and the first step of $\mathrm{Ho} / 850 / 33$, both of them being performed at strain-rates in the same order of magnitude $\left(5^{*} 10^{-5} \mathrm{~s}^{-1}\right.$ and $\left.2 * 10^{-5} \mathrm{~s}^{-1}\right)$ and both being deprived of any inheritance from earlier strain history. Experiment Ho/750/6 shows hardening with strain (Fig. 3a) whereas experiments Ho/850/33 first step reaches a steady state (Fig. 3b). Experiment Ho/750/6 (>200 MPa at $2 * 10^{-5} \mathrm{~s}^{-1}$, Fig. 3a) reaches higher stress than experiment $\mathrm{Ho} / 850 / 33\left(<20 \mathrm{MPa}\right.$ at $5 * 10^{-5} \mathrm{~s}^{-1}$; Fig $\left.3 \mathrm{~b}\right)$.

\subsubsection{The heterogeneous gneiss PX28}

At $10^{-4} \mathrm{~s}^{-1}$, experiment He/850/19 reaches higher stress (circa $60 \mathrm{MPa}$ Fig. 3c) than 294 experiments He/900/21-32 (ca. $10 \mathrm{MPa}$, Fig. 3d). The same observation is true for $10^{-3} \mathrm{~s}^{-1}$ 
(>70 $\mathrm{MPa}$ in $\mathrm{He} / 850 / 19$ vs ca. $30 \mathrm{MPa}$ in He/900/21-32; Figs. $3 \mathrm{c} \&$ d). At $850^{\circ} \mathrm{C}$ in

$296 \mathrm{He} / 850 / 19$, the stress vs. strain curves show a stress peak at ca. 7\% strain followed by the

297 very beginning of a strength decrease (Fig. 3c). At $900^{\circ} \mathrm{C}$, in experiment He/900/21-32,

298 steady state is attained after ca. 10\% strain with flow stresses about $10 \%$ of the confining

299 pressure at $10^{-3} \mathrm{~s}^{-1}$ (Fig. 3d).

$300 \quad$ 'Insert figure 3 here'

301

4.3 Microstructures at sample scale $(1 \mathrm{~mm}-1 \mathrm{~cm})$

\subsubsection{Microstructures in the homogeneous gneiss NOP1}

304 To a first order, the deformation distribution in both experiments $(\mathrm{Ho} / 750 / 6$ \& $305 \mathrm{Ho} / 850 / 33)$ is mostly homogeneous given the near barrel shaped end-cores with smooth edges 306 and the lack of penetrative shear zones cross-cutting either sample (Fig. 4). In the low - glass 307 fraction experiment Ho/750/6, little strain localization is observed, as shear zones are rare and 308 small (only 8 observed) and connect to sample edges (Fig. 4a). Geometrically these shear 309 zones occur as planes with angles greater than $25^{\circ}$ to the experimental compression direction 310 (black arrows in Fig. 4). However, the large range of angles and the small number of shear 311 zones prevent any statistical analysis. In high glass fraction experiment Ho/850/33, only five

312 shear zones are observed and they are all connected to sample boundaries without penetrating 313 more than a few mm into the sample (shear-zones reported in Fig. 4b were first observed on

314 SEM images).

315 'Insert figure 4 here' 
In the layered gneiss (PX28), deformation at core - scale is more heterogeneous as

319 primarily shown by the jagged edges of core samples (Fig. 5). In the experiment with low 320 glass content, run at $850^{\circ} \mathrm{C}(\mathrm{He} / 850 / 19)$, deformation is mainly accommodated by two corescale shear zones (in red in Fig. 5a). Deflection of the pre-existing foliation along the two shear zones defines "shear zone boudins" as classified by Goscombe et al. (2004). Shear zones orientations were systematically measured (angle to the experimental compression 324 direction) from image analysis and the minerals they affect systematically noted. We distinguish mica-mica, mica-quartz, and quartz-quartz shear zones. Their offset being the same order of magnitude or smaller than aggregate sizes, the association of minerals on each side of shear zones is interpreted to be the shear zone initiation site. In He/850/19 experiment, shear zones concentrate in or along mica - rich layers (Fig. 5a), as only two are observed 329 along quartz - quartz contacts (Fig. 6a). In experiment with the higher melt fraction, conducted at $900^{\circ} \mathrm{C}(\mathrm{He} / 900 / 21-32)$, shear zones are distributed within or between micaceous 331 and quartzo-feldspathic layers (Figs. 5b \& 6b).

The average orientation of shear zones is close to $45^{\circ}$ within both experiments (Fig. 6). In details, in He/850/19, shear zones lack an angle to experimental compression direction less than $20^{\circ}$, and most angles are between $20^{\circ}$ and $60^{\circ}$ with a mean for the population of about $45^{\circ}$ (Fig. 6a). Shear zones with larger angles to the experimental compression direction

337 develop mainly in micas-rich layers. At $900^{\circ} \mathrm{C}$ and higher melt fraction (He/900/21-32), shear

338 zones have lower incidence values with a more pronounced peak in the $40-45^{\circ}$ (Fig. $6 \mathrm{~b}$ ).

'Insert figure 6 here'

In He/900/21-32, some quartz-feldspars layers are truncated into few millimetres-long 341 symmetric boudins while the mica - and glass - rich layers tend to occur within boudin-necks 
342 (Figs. 5b \& 7a). Here, boudins are mostly symmetrical with little slip along a single shear

343 band on the inter-boudin surface (no slip boudinage from Goscombe et al., 2004).

344 'Insert Figure 7 here'

4.4 Microsctructures at grain-scale ( $\mu m-m m)$

\subsubsection{Microstructures in the homogeneous gneiss NOP1}

In Ho/750/6, mica grains were deformed by syn-experimental kink bands (Fig. 8a, red lines in Fig. 4), whereas Ho/850/33 contains only a few kink bands. Some biotites with sigmoid-like shapes are observed in both samples (Figs. 8c \& d). different sizes, with each fragment being surrounded by glass, forming an interconnected 355 glass - filled fracture network (Figs. 8c, d and e). Such networks inside quartz grains have larger expansion in Ho/850/33 (Fig. 8e) than in Ho/750/6 (Fig. 8c). In these networks, glass is generally free of newly formed peritectic phases (Fig. 8e).

'Insert figure 8 here'

\subsubsection{Microstructures in the heterogeneous gneiss PX28}

A major difference between both experiments (He/850/19 \& He/900/21-32) is that muscovite is not observed anywhere in He/900/21-32, which means that muscovite completly

363 reacted during the experiment. As the only known reaction involving muscovite is dehydration melting, we propose that muscovite entirely disappeared by dehydration melting. 
observed. Some biotites are broken in small pieces $(<20 \mu \mathrm{m})$ and aligned along a plane that we interpret as a shear zone (Fig. 7a). Biotites oriented perpendicularly to their initial orientation and surrounded by glass, also containing newly formed peritectic phases, are observed in He/900/21-32 (Fig. 7b), implying flow of biotite during deformation.

Newly formed peritectic phases are mainly observed in glass films along mica grains and oriented parallel to the foliation. However in both experiments, changes in newly formed peritectic phase orientation are observed along glass veins inside quartz grains (e.g. in He/900/21-32 in Fig. 7c). This change in orientation of newly formed peritectic phases is interpreted as marking flow of the peritectic phases-bearing melt. Quartz grains show syn-deformation lobate boundaries and grain-size reduction (Figs. $9 \mathrm{a} \& \mathrm{~b}$ ), which are assumed to be due to partial consumption during melting reaction. Outside of mica - rich layers, quartz and feldspar grains show offsets and relative displacements of grains with respect to each other without evidence of cataclastic deformation of grains, nor intracrystalline plasticity (Fig. 9c). The observation that glass fills all pores and boundaries

380 between the matrix grains supports a melt-assisted granular flow. Quartz and feldspar 381 breakage is observed in few locations (e.g. Fig. 7a), within shear zones. In He/900/21-32 experiment, very few glass-filled cracks within quartz and feldspar grains are observed (Fig. 383 7c).

'Insert figure 9 here'

4.5 Glass distribution

\subsubsection{Glass distribution in the homogeneous gneiss NOP1}

In experiments on the homogeneous gneiss (NOP1), glass content at $850^{\circ} \mathrm{C}$ is 5.5 time 


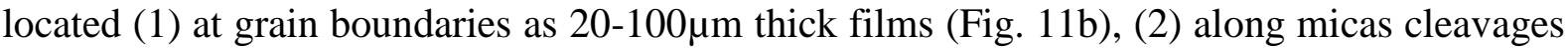

391 forming few $\mu \mathrm{m}$-size pockets (black arrows in Fig 11b) or (3) in quartz grains as injections 392 (blue triangles in Fig. 4; Fig. 11c). Glass injections, depleted in newly formed peritectic 393 minerals, are generally thicker at the boundary of their host grain or grain fragment (Figs. 8e 394 \& Fig. 11c) and narrower within quartz grains, which allows determination of glass 395 movement direction, i.e. from mica grains toward quartz grain aggregates. Glass-filled cracks 396 within quartz-supported network (e.g. Figs. 8d \& 11d) is systematically poor in newly formed 397 peritectic phases (in blue in Fig. 11d). Even if the zone illustrated in Fig. 11c is located 398 between two shear zones (thick dashed lines), its glass content is less than the zone in Fig. 399 11d, located away of any shear zone. The fact that shear zones do not correspond with high 400 glass fraction areas is observed over the whole sample (e.g. Figs. 8d \& 10b) and in Ho/750/6.

401 No clear relation between glass distribution and shear zones localization can be identified 402 from sample examination.

In sample cores from both experiments, the main population of glass films and pockets orientation is almost perpendicular to the experimental compression direction: $40 \%$ of the glass pockets and films are between 80 and $120^{\circ}$ in $\mathrm{Ho} / 750 / 6,26 \%$ in Ho/850/33 (Dark grey

406 population in rose diagrams in Fig. 10). A second population of glass orientations is present in $407 \mathrm{Ho} / 750 / 6$ and is oblique to the experimental compression direction (Fig. 10a). In both 408 experiments, glass injections in quartz (glass location 3, see above) are sub-parallel to 409 experimental compression direction (light grey population in rose diagrams in Fig. 10).

\section{0 'Insert figures 10 and 11 here'}

\subsubsection{Glass distribution in the heterogeneous gneiss PX28}

In order to discuss glass distribution in heterogeneous gneiss PX28, several zones have

414 been carefully mapped as illustrated in Fig. 12. In He/850/19, one zone encompassing one 
quartz-rich layer and one mica-rich layer have been delineated. Size of the zone $(5 \mathrm{~mm} \times 5$

$416 \mathrm{~mm}$ ) was determined so that enough grains were considered for statistical analysis of the rose

417 diagrams (more than 800 values for each). For He/900/21-32, two distinct zones were chosen.

418 One (Zone 1) is representative of the upper part of the core with alternations of 2 to $3 \mathrm{~mm}$

419 thick, continuous quartz-rich layers with thinner continuous mica-rich layers. Zone 2 was

420 chosen to represent the lower part of the sample with disrupted mica-rich horizons within a

421 quartz-rich matrix. Once again, the size of each zone was determined so that enough grain

422 boundaries were mapped.

In experiments on the heterogeneous gneiss (PX28), mean glass content is $19 \pm 6 \%$ at $850^{\circ} \mathrm{C}(\mathrm{He} / 850 / 19)$ and ranges from $21 \pm 7$ to $32 \pm 6 \%$ at $900^{\circ} \mathrm{C}(\mathrm{He} / 900 / 21-32$; Fig. 12 and Table 1). Glass content has been measured across quartz - and mica - rich layers alternations (Fig. 12). Glass content in mica - rich layers $(22 \%$ in He/850/19, Fig. 12a, and $26 \%$ in He/900/21-32, Fig. 12b) is systematically higher than in quartz-rich layers $(13 \%$ in $\mathrm{He} / 850 / 19$, Figure $12 \mathrm{a}$, and $14 \%$ in $\mathrm{He} / 900 / 21-32$, Fig. 12 b). At $850^{\circ} \mathrm{C}$ (in $\mathrm{He} / 850 / 19$ ), glass is present around muscovite grains, which are still present. At $900^{\circ} \mathrm{C}$ (i.e. He/900/21-32), muscovite is not observed anymore. Glass is present along and within biotite grains (Figs. 13b \& c). In quartz - rich layers, glass is mostly present at grain boundaries (Fig. 13c \& d), but in 432 smaller amount than in mica - rich layers (13\% in He/850/19 and 14\% in He/900/21-32; Fig. 12). In He/900/21-32, glass is present in inter-boudin position within quartz - rich layers 434 (inter-boudin illustrated in Figs. 7a, 13b and located in Fig. 5), where local high glass-fraction is reached (up to $41 \%$ in Fig. 13b). In both experiments, melt (observed as glass) is collected 436 within shear zones as illustrated by the example given in Fig. 7a. Glass is also present along 437 cracks in quartz or plagioclase (Figs. 7c \& white arrows in 13c) and at quartz-plagioclase 438 grain boundaries (Fig. 13d). Newly formed peritectic phases are present in glass pockets or 439 glass films near micas (Fig. 13). Orientation of remaining micas flakes and solid reaction 
products evidence that they were sucked toward dilatant sites like boudin-neck and shear

441 zones together with the moving melt (Figs. 7b, c \& d). Heterogeneous distribution of glass is

442 documented in He/900/21-32. Fig. 12b shows two different zones that have different glass

443 fractions of $21 \pm 7 \%$ (zone 1) and $32 \pm 6 \%$ (zone 2). Zone 1 contains a $1-3 \mathrm{~mm}$ - thick quartz -

444 rich layer and is relatively poor in glass. Zone 2 contains more micaceous layers and shows a 445 greater glass content.

446 In both experiments considering the mica - rich and quartz - rich layers together, glass 447 areas have a strong preferred orientation normal to compression direction (rose diagrams in 448 Fig. 12). Nevertheless glass orientation varies between mica - rich and quartz - rich layers. In $449 \mathrm{He} / 850 / 19$ (Fig. 12a), the dominant population of glass veins runs parallel to experimental 450 compression direction in quartz-rich layers (low angle bins in rose diagram), while dominant 451 population in mica-rich layers is perpendicular to experimental compression direction and 452 actually parallel to mica elongation axis. In He/900/21-32, orientation patterns are more 453 complex. Within the upper quartz layer of zone 1, a significant population of veins with low 454 angles to the experimental compression direction also appears (16\% of all measured values), 455 while they are absent in the most mica-rich sub-layer despite representing $26 \%$ of all 456 measured values for the entire mica rich layer. In zone 2, glass is mainly oriented 457 perpendicularly to experimental compression direction (Fig. 12b). 'Insert figures 12 and 13 here'

\section{Discussion}

\subsection{Limits of this study}

Our aim is to investigate the effect of protolith initial texture and related incipient melt 463 distribution on melt flow during deformation. For this purpose, two sets of experiments on two natural protoliths with particular experimental conditions were performed. Experimental 
temperatures were chosen to get water - present and water - absent muscovite melting

466 reactions. A drawback of this approach to experimental temperature control is that these changing conditions had an impact on melt viscosity that could not be measured in our experiments. Nevertheless, published data about haplogranitic melts (Dingwell et al., 1996) show that above 1 wt $\% \mathrm{H}_{2} \mathrm{O}$ and $700^{\circ} \mathrm{C}$, impacts of temperature and hydration are limited and effective viscosities are between $10^{7}$ and $10^{4}$ Pa.s, which is more than 6 orders of magnitude below the effective viscosity of surrounding rock $\left(10^{13}\right.$ Pa.s for a dry Westerly granite (Carter \& Tsenn, 1987) strained at $1.10^{5} \mathrm{~s}^{-1}$ and $750^{\circ} \mathrm{C}$ ).

Strain rate is another parameter that changes between experiments. The experiments with different strain rate steps $(\mathrm{Ho} / 850 / 33, \mathrm{He} / 850 / 19 \& \mathrm{He} / 900 / 21-32)$ show that stress increases with strain rate (Fig. 3). For instance, experiment Ho/850/33 exhibits an increase from 9.2 to $31 \mathrm{MPa}$ when the strain rates increases from $1 * 10^{-5}$ to $1.25^{*} 10^{-3} \mathrm{~s}^{-1}$. Stress is multiplied by 3.3 whereas strain rate is multiplied by 125 , thus stress increase with strain rate remains limited. Strain rates therefore seems to be a second-order.

\subsection{The meaning of glass locations and glass amounts}

Until now, we have been describing glass locations and amounts in our experiments.

However, our aim is to look at melt distribution and melt flow associated with deformation of partially molten rocks. Thus, it is important to understand what "glass" represents. When 484 performing deformation, the temperature was higher than $750^{\circ} \mathrm{C}$, which is far above the glass to melt transition (Webb and Knoche, 1996). This state means that during deformation, melt was present, and that the two gneisses were indeed partially molten. The transition from melt to glass occurs at the end of the deformation event, when the oven is turned off leading to 488 rapid temperature decrease. Glass would therefore represent the melt, as usually considered 489 (e.g. Arzi, 1978; Misra et al., 2009). Following this logic, glass locations and glass amount 
represent melt locations and melt amounts, respectively. Thus, we will now speak of melt 491 instead of glass.

\subsection{Potential link between stress vs strain curves and microstructures}

Experiments on the homogeneous gneiss NOP1 show different stress vs. strain curves:

the low temperature and low melt-content experiment $(\mathrm{Ho} / 750 / 6)$ shows hardening whereas the experiment performed at higher temperature and melt content $(\mathrm{Ho} / 850 / 33)$ shows steady state at high finite strain (Fig. 3). Hardening behaviour was previously observed in experiments for highly crystallized magma (crystal fractions larger than 0.5 and up to 0.8 ; Arbaret et al., 2007; Forien et al., 2011). From these experiments performed in torsion, the authors concluded that strain was mainly accommodated by the development of synthetic normal Riedel - type shear zones that, associated with Trust - type shear bands, formed an anastomosed network of shear zones delimitating lenses of less deformed melt-bearing zones. In the shear zones, intragranular fracturing (i.e. crystal breakage) was identified (Arbaret et $a l .$, 2007). This crystal breakage is inferred to be related to intense stress at contact between grains in localized zones submitted to large shear strains (Forien et al., 2013). In addition, 506 they documented shear hardening in experiments where the crystals suffered intense 507 fracturing, whereas steady - state deformation occurred in experiments without any 508 generalized crystal breakage (Forien et al., 2011). In our series of experiments on the 509 homogeneous gneiss NOP1, quartz - grain breakage (green dashed line in Fig. 4a and cracks 510 in Fig. 8b) is observed in Ho/750/6 while it is absent for the deformation experiment at higher 511 temperature with a larger melt fraction (Ho/850/33, Fig. 4b). Even if shear zones and crystal 512 breakage are less developed in Ho/750/6 than in the study of Forien et al (2011), we conclude that strain hardening behaviour of Ho/750/6 probably results from localized shear zones 
514 together with regions of grain breakage that mainly accommodated the bulk sample deformation.

Experiments on the heterogeneous gneiss PX28 also exhibit different behaviours (Fig. 3). He/900/21-32 experiment is characterized by stable low shear stress at large strains, whereas He/850/19 seems to show a peak of high stress followed by the very beginning of shear softening. A similar behaviour with shear softening following the high - stress peak was experimentally reproduced in crystal-melt mixtures by Picard et al. (2011). They showed that this behaviour was associated with the intense development of discrete Riedel shear zones that localized the deformation. Numerous small shear zones are observed in He/900/21-32. Based on this previous study, we conclude that the rheological behaviour exhibited by the experiment $\mathrm{He} / 850 / 19$ is controlled by the early initiation of shear zones that subsequently developed over the entire volume of the deformed core. In He/900/21-32, shear zones are less developed and do not traansect over the entire volume of the sample, so the strain-softening behaviour is absent.

The difference between He/850/19 showing strain softening and He/900/21-32 showing a steady state could also be explained by their difference in shear zone orientations.

530 Indeed, shear zones development and geometry are indicative of mechanical properties of the

531 studied aggregates (Veermer and De Borst, 1984; Veermer, 1990). Development of compactant shear zones is expected to induce weakening of the overall material, while dilatant shear zones are associated with bulk hardening (Vermeer and De Borst, 1984).

534 Compactant (respectively dilatant) shear zones (with negative, respectively positive, 535 compaction angles) are expected to develop at angles higher (respectively lower) to $\sigma_{1}$ 536 (equivalent to the experimental compression direction in our study) in the Roscoe model 537 (Vermeer, 1990) considered as relevant for high confining pressures, as in our experiments 538 (Le Pourhiet, 2013). The observed distributions could reflect this contrast with shear zones 
developing at higher angle in He/850/19 than in He/900/21-32. Their distribution in quartz -

540 or mica - rich layer could also explain these differences. In He/900/21-32, most low-angle 541 shear zones were measured in quartz layers, while high-angle shear zones were mostly 542 measured in mica - rich layers in both He/900/21-32 and He/850/19 experiments. Within the 543 layered gneiss, melt produced by mica partial melting is present in greater amounts in mica544 rich layers, indicating that partial melting occured preferentially in mica - rich layers. In 545 addition, microstructural observations show that melt primarily located in the sheared 546 micaceous layers flowed toward the quartz-feldspatic layers and filled the low-angle shear 547 zones. Thus, one could consider that shear zones developing in mica - rich layers release 548 melt, and therefore are compactant, while shear zones developing in quartz - rich layers trap 549 melt, and therefore dilate. In He/900/21-32, development of dilatant shear zones in quartz and 550 compactant shear zones in mica promote drainage of melts from mica - rich layers to quartz 551 rich layers without significant weakening, while in He/850/19, shear zones in mica - rich 552 layers prevail and anastomose in a sample-scale compacting shear zone inducing overall 553 weakening.

\subsection{Impacts of gneissic layering on melt flow}

Melt distribution within partially molten rocks first reflects the initial distribution of melt production sites. In our experiments, we focused on water - present and muscovite 558 dehydration melting reactions to test the change in melt distribution during deformation of 559 two kinds of partially molten rocks: one rock with incipient melt homogenously distributed 560 (NOP1) and one with a heterogeneous melt distribution that mimics gneissic layering of the protolith (PX28). In the case of the homogeneous gneiss NOP1, sites of melt production are directly 
which means that in both experiments $(\mathrm{Ho} / 750 / 6$ \& Ho/850/33) melt is produced all over the sample. This interpretation is corroborated by the fact that melt contents calculated in different locations are equal at the sample scale. Results of the experiments performed on the homogeneous migmatite show that melt movement is limited to melt - filled injections in quartz grains at $\mu \mathrm{m}$-scale and melt does not flow from initiation sites into possible pathways such as shear zones. Shear zones are observed in the deformed homogeneous gneiss (Fig. 4). However, they do not correspond with high melt areas, implying that they do not concentrate melt, which means that melt did not move toward shear zones. The lack of melt movement may be explained by (1) limited melt - pressure gradients within the sample, (2) limited connectivity of the melt or (3) a high melt viscosity. A high viscosity may be rejected because the melt was hydrated, which means that its viscosity is low (Shawn, 1965). Melt connectivity could not be estimated in this study. However, previous studies on hydrated partially molten granite or aplite, i.e. two homogeneous rocks, show that melt is connected as soon as $7 \%$ melt is present (see in Rosenberg and Handy, 2005). Mean melt content in Ho/750/6 is really close to $7 \%$ (Table 1), even if it may be less locally. Thus, melt connectivity is likely to have occurred, at least in some portions of the sample volume. However, melt connectivity is not sufficient to promote melt flow. A driving force is needed. Therefore, limited melt transport more probably relates to limited melt - pressure gradient within the sample. As melt is produced homogeneously at sample scale, there is no melt concentration gradient and thus no melt pressure gradient is created. The lack of melt - pressure gradient probably prevents melt movement. Thus, the melt distribution in the homogeneous gneiss NOP1 is mainly controlled by the location of melting reactants, which is controlled by the initial protolith fabric and the initial spatial distributions of the grains for the different mineral components (known for static conditions, Mehnert et al., 1973). 
In contrast, melt is heterogeneously distributed in experiments on the heterogeneous gneiss PX28 (He/850/19 \& He/900/21-32). Evidences of strong melt flow as exemplified by strong alignment of peritectic minerals and the presence of melt+peritectic minerals in shear zones and interboudin positions are observed for the deformed layered migmatite (PX28; Fig. 7). In these experimentally deformed rock samples, gneissic layering strongly enhanced the production and coalescence of melt along mica - rich layers. This enhancement causes a

594 strong pressure gradient between the two compositionally different layers, i.e. between mica rich and quartz - rich layers. This heterogeneous distribution of melt increases the strength difference and enhances deformation partitioning between mica - rich and quartz - rich layers. This contributes to localizing deformation along shear zones and boudin-necks acting as low melt - pressure sites into which melt migrates efficiently.

\subsection{Comparison with natural migmatites}

In nature, incipient partial melting leads to the formation of metatexite, where paleosome dominates, and where crystallized melt appears as leucosomes arranged as elongated pockets that parallel the protolith planar fabric (Fig. 14). A similar pattern of melt distribution parallel to protolith foliation is observed in our experiments for both homogenous and heterogeneous starting materials but with differences in melt flow during experiment. We propose that the particular orientation of melt perpendicular to the compression direction reflects a strong control of the initial orientation of reactants. This hypothesis is compatible

608 with the process of microstructure development proposed by Holyoke and Rushmer (2002), 609 (Figs. 13 and 14 in Holyoke and Rushmer, 2002) In the case of the homogeneous gneiss NOP1, melt distribution is not disturbed by 611 deformation and melt does not migrate. Melt remains located in films perpendicular to 612 shortening direction (Figs. 10 \& 12), as already observed by Holyoke \& Rushmer (2002), 
613 which is opposite to results from numerous previous studies where melt concentrates within

614 cracks and grain boundaries that are parallel to the shortening direction (e.g. van der Molen \& 615 Paterson, 1979; Rutter \& Neumann, 1995).

616 For the heterogeneous migmatite (PX28), the early melt distribution is modified 617 during deformation and subsequent melt migration. Shearing along melt-bearing micaceous 618 layers, shear bands development and boudinage provide efficient pathways for melt 619 migration. The co-location of melt products with such positions is observed within natural 620 migmatites where due to competency contrast between various layers, leucosome is located in 621 dilatant structural sites, such as the spaces between boudins, in pressure shadows, or in 622 fractures in the more competent layers of migmatites (Figs. 14b, c). Occurrences of 623 leucosomes, which derived from crystallized melt, at the neck of boudins are described in 624 numerous terrains (e.g. Port Navalo French Armorican Massif: Marchildon \& Brown, 2003; 625 British Columbia: Sawyer, 2008; Western Gneiss Region Norway: Ganzhorn et al., 2014) and 626 may be compared to melt flow observed in experiments on the heterogeneous gneiss PX28, even if the scales are different. Shear zones and more particularly the ones that transect mica628 rich and quartz-rich layers, build connection between high-pressure and low-pressure zones, 629 and thus, enhance melt flow as observed in nature with crosscutting leucosomes feeding 630 granite dyke networks.

634 layered gneiss shows that initial compositional layering of the protolith have a great influence 635 on melt distribution and melt flow. In the homogeneous gneiss, the main result is the lack of 636 melt migration toward melt collection zones during deformation experiments. In contrast, 637 experiments on the strongly layered gneiss show deformation partitioning between mica - 
638 rich and quartz - rich layers, creation of interconnected pathways that drain and collect melt

639 efficiently. The presence of gneissic layering with the alternation of fertile and non-fertile 640 layers enhances melt - pressure gradients, deformation partitioning with boudinage and shear 641 zone development, driving melt flow through the partially-molten rock. Consequently melt 642 flow within a metatexite is greatly enhanced if the protolith of the partially molten rock shows 643 an inherited gneissic layering.

644

\section{Acknowledgment}

646 We thank C. Teyssier and an anonymous reviewer for thorough reviews and W. 647 Dunne for his attentive care and helpful review. This study benefited from discussions and 648 has received funding from the European Research Council (ERC) under the seventh 649 Framework Program of the European Union (ERC Advanced Grant, grant agreement No 650 290864).

\section{References}

653 Arbaret, L., Bystricky, M., Champallier, R., 2007. Microstructures and rheology of hydrous synthetic magmatic suspensions deformed in torsion at high pressure. Journal of Geophysical Research, 112, B10208.

Arzi, A.A., 1978. Critical phenomena in the rheology of partially melted rocks. Brown, M., \& Solar, G.S, 1998, Granite ascent and emplacement during contractional deformation in convergent orogens. Journal of Structural Geology, v20, 9-10, 1365-1393.

659 Boettcher, A.L., Wyllie, P.J., 1969. Phase relationships in the system NaAlSiO4-SiO2-H2O to 35 kilobars pressure. American Journal of Science, 267, 875-909. 
661 Brown, M., Solar, G.S, 1998. Granite ascent and emplacement during contractional deformation in convergent orogens. Journal of Structural Geology, 20, 1365-1393.

663 Cadwell, W.B., Klemperer, S.L., Rai, S.S., Lawrence, J.F., 2009. Partial melt in the upper664 middle crust of the northwest Himalaya revealed by Rayleigh wave dispersion. Tectonophysics, 477, 58-65.

666

667

668

669

670

671

672

673

674

675

676

677

678

679

680

681

682

Castro, A., Guillermo Corretgé, L., El-Biad, M., El-Hmidi, H., Fernandez, C., Patiño-Douce, A.E., 2000. Experimental Constraints on Hercynian Anatexis in the Iberian Massif, Spain. Journal of Petrology, 41, 10, 1471-1488.

Carter, N.L., Tsenn, M.C., 1987. Flow properties of continental crust. Tectonophysics, 136, 27-63.

Champallier, R., 2005. Déformation expérimentale à Haute Température et Haute Pression de magmas partiellement cristallisés. 213 p.

Champallier, R., Bystricky, M., Arbaret, L., 2008. Experimental investigation of magma rheology at $300 \mathrm{MPa}$ : from pure hydrous melt to 76 vol.\% of crystals. Earth and Planetary Science Letters, 267, 3-4, 571-583.

Clemens, J.D., Vielzeuf, D., 1987. Constraints on melting and magma production in the crust. Earth and Planetary Science Letters, 86, 2-4, 1987.

Cooper, R.F., Kohlstedt, D.L., 1984. Solution-precipitation enhanced diffusional creep of partially molten olivine-basalt aggregates during hot-pressing. Tectonophysics, 107, 207-233.

Daines, M.J., Kohlstedt, D.L., 1997. Influence of deformation on melt topology in peridotites. Journal of Geophysical Research: Solid Earth, 102, 10257-10271. 
683 Dingwell, D.B., Romano, C., Hess, K.V., 1996. The effect of water on the viscosity of a

684

685

686

687

688

689

690

691

692

693

694

695

696

697

698

699

700

701

702

703

704

705 haplogranitic melt under PTX conditions relevant for silicic volcanism. Contributions to Mineralogy and Petrology, 124, 19-28.

Forien M., Arbaret L., Burgisser A., Champallier R., 2011. Crystal breakage in magmas: experimental constrains. Journal of Geophysical Research, 116, doi:10.1029/2010JB008026.

Ganzhorn, A.C., Labrousse, L., Prouteau, G., Leroy, C., Vrijmoed, J., Andersen, T.B., Arbaret, L., 2014. Structural, petrological and chemical analysis of syn-kinematic migmatites: insights from the Western Gneiss Region, Norway. Journal of Matamorphic Geology, 32, 647-673.

Goscombe, B.D., Passchier, C.W., Hand, M., 2004. Boudinage classification: end-member boudin types and modified boudin structures. Journal of Structural Geology, 26, 739763.

Hashim L., Gaillard F., Champallier R., Le Breton N., Arbaret L., Scaillet B., 2013. Experimental assessment of the relationships between electrical resistivity, crustal melting and strain localisation beneath the Himalayan-Tibetan belt. Earth and Planetary Science Letter, 373, 20-30

Holyoke III, C.W., Rushmer, T., 2002. An experimental study of grain scale melt segregation mechanisms in two common crustal rock types. Journal of Metamorphic Geology, 20, 5, 493-512.

Kretz, R., 1983. Symbols for rock-forming minerals. American Mineralogist, 68, 277-279.

Kohlstedt, D.L., Zimmerman, M.E., 1996. Rheology of partially molten mantle rocks. Annual Review of Earth and Planetary Sciences, 24, 41-62. 
Labrousse, L., Prouteau, G., Ganzhorn, A.C., 2011. Continental exhumation triggered by partial melting at ultra-high-pressure. Geology, 39, 1171-1174.

Laporte, D., Watson, E. B., 1995. Experimental and theoretical constraints on melt distribution in crustal sources: the effect of crystalline anisotropy on melt interconnectivity. Chemical Geology, 124, 161-184.

Launeau, P., Robin P.-Y., 1996. Fabric analysis using the intercept method. Tectonophysics, $267,1-4,91-119$.

Launeau, P., Archanjo, C.J., Picard, D., Arbaret, L., Robin, P.-Y., 2010. Two- and threedimensional shape fabric analysis by the intercept method in grey levels. Tectonophysics, 492, 1-4, 230-239.

Le Pourhiet, L., 2013. Strain localization due to structural softening during pressure sensitive rate independent yielding. Bulletin de la Société Géologique de France, 184, 4-5, 357371.

Marchildon, N., Brown, M., 2003. Spatial distribution of melt-bearing structures in anatectic rocks from Southern Brittany, France: implications for melt transfer at grain- to orogenscale. Tectonophysics, 364, 3-4, 215-235.

Mehnert, K.R., Büsch, W., Schneider, G., 1973. Initial melting at grain boundaries of quartz and feldspar in gneisses and granulites. Neues Jahrbuch des Mineralogie Monatshefte, 165-183.

Misra, S., Burlini, L., Burg, J.P., 2009. Strain localization and melt segregation in deforming metapelites. Physics of the Earth and Planetary Interiors, 177, 173-179.

Misra, S., Burg, J.P., Mainprice, D., Vigneresse, J.-L., 2014. Rheological transition during large strain deformation of melting and crystallizing metapelites. Journal of Geophysical Research - Solid Earth 119, doi:10.1002/2013JB010777. 
Nelson, K. D., Zhao, Wenjin, Brown, L. D., Kuo, J., Che, Jinkai, Liu, Xianwen, Klemperer, S. L., Makovsky, Y., Meissner, R., Mechie, J., Kind, R., Wenzel, F., Ni, J., Nabelek, J., Leshou, Chen, Tan, Handong, Wei, Wenbo, Jones, A. G., Booker, J., Unsworth, M., Kidd, W. S. F., Hauck, M., Alsdorf, D., Ross, A., Cogan, M., Wu, Changde, Sandvol, E., Edwards, M., 1996. Partially Molten Middle Crust Beneath Southern Tibet: Synthesis of Project INDEPT Results. Science, 1684-1688.

Patiño Douce, A.E., Harris, N., 1998. Experimental Constraints on Himalayan Anatexis. Journal of Petrology, 39, 4, 689-710.

Picard, D., Arbaret, L., Pichavant, M., Champallier, R., Launeau, P., 2011. Rheology and microstructure of experimentally deformed plagioclase suspensions. Geology, 39, 747750.

Rosenberg, C.L., Handy, M.R., 2005. Experimental deformation of partially melted granite revisited: implications for the continental crust. Journal of Metamorphic Geology, 23, $19-28$.

Rudnik, R.L., 1995. Making continental crust. Nature, 378, 571-578.

Rutter, E.H., Neumann, D.H.K., 1995. Experimental deformation of partially molten Westerly granite under fluid-absent conditions, with implications for the extraction of granitic magmas. Journal of Geophysical Research, 100, 15,697-15,715.

Rutter, E.H., Brodie, K.H., Irving, D.H., 2006. Flow of synthetic, wet, partially molten « granite » under undrained conditions: An experimental study. Journal of Geophysical research, 111, B06407.

Sawyer, E.W., 2008. Atlas of Migmatites. The Canadian Minearalogist Special Publication, 9, 371.

Shawn, H.R., 1965. Comments on viscosity, crystal setting, and convection in granitic magmas. American Journal of Science, 263, 120-152. 
Solar, G.S., Brown, M., 2001. Petrogenesis of Migmatites in Maine, USA: Possible Source of Peraluminous Leucogranite in Plutons? Journal of Petrology, 42, 4, 789-823.

Spear, F.S., Cheney, J.T., 1989. A petrogenitic grid for pelitic shichts in the system $\mathrm{SiO}_{2^{-}}$ $\mathrm{Al}_{2} \mathrm{O}_{3}-\mathrm{FeO}-\mathrm{MgO}-\mathrm{K}_{2} \mathrm{O}-\mathrm{H}_{2} \mathrm{O}$. Contributions to Mineralogy and Petrology, 101, 149-164.

Trap, P., Faure, M., Lin, W., Augier, R., Fouassir, A., 2011. Syn-collisional channel flow and exhumation of Paleoprotérozoic high pressure rocks in the Trans-North China Orogen: the critical role of partial melting and orogenic bending. Gondwana Research, 20, 498515.

Turmakina, E., Misra, S., Burlini, L., Connolly, J.A.D., 2011. An experimental study of the role of shear deformation on partial melting of a synthetic metapelite. Tectonophysics, $503,92-99$.

van Der Molen, I., Paterson, M.S., 1979. Experimental deformation of partially melted granite. Contributions to Mineralogy and Petrology, 70, 299-318.

Vermeer, P.A., De Borst, R., 1984. Non-Associated Plasticity for Soils, Concrete and Rock. HERON, 29, 1984.

Vermeer, P.A., 1990. The orientation of shear bands in biaxial tests. Geotechnique, 40, 223236.

Webb, S., Knoche, R., 1996. The glass-transition, structural relaxation and shear viscosity of silicate melts. Chemical Geology, 128, 165-183.

Zimmerman,M. E., Zhang, S., Kohlstedt, D. L., \& Karato, S. I., 1999. Melt distribution in mantle rocks deformed in shear. Geophysical Research Letters, 26, 1505-1508. 
781 Figure 1: Initial structure of the two starting materials: the homogeneous gneiss NOP1 $(a, b)$ 782 and the heterogeneous gneiss PX28 (c, d). a) Cross-polarized image of NOP1 thin section 783 showing the homogeneous distribution of phases. b) Grain size differences between quartz 784 aggregates and plagioclase+mica aggregates in NOP1 (cross-polarized image). c) Crosspolarized image of thin section showing mineral layering in PX28. d) Mica-rich layer showing shear-zones in PX28. Pl: plagioclase, Qtz: quartz, Bt: biotite, Ms: Muscovite.

Figure 2: SEM images of textures related to partial melting reactions. a) Glass between muscovite and quartz in hydrated undeformed homogeneous gneiss NOP1 (NOP1-B in Table 1), indicating water - present partial melting.

b) Glass between quartz and plagioclase indicating the following water - present partial melting reaction: plg+qtz+H2O=Melt. The the experiment at $900^{\circ} \mathrm{C}$ on the heterogeneous gneiss, indicating the muscovite - dehydration partial melting. A similar reaction occurs in NOP1 (NOP1-A). d) Newly-formed peritectic phase flow around biotite. Pl: Plagioclase, Ms: muscovite, Bt: biotite, Qtz: quartz, Gl: glass.

Figure 3: Stress vs. strain curves for both sets of experiments. Numbers labelled on curves are strain rates.

800 Figure 4: Sample-scale deformation in the homogeneous gneiss NOP1 at $750^{\circ} \mathrm{C}$ (a) and $801850^{\circ} \mathrm{C}$ (b). Black arrows: the experimental compression direction. Dashed line rectangles: 
804 Figure 5: Sample - scale deformation in the heterogeneous gneiss PX28 at $850^{\circ} \mathrm{C}$ (a) and

$805900^{\circ} \mathrm{C}$ (b). For each experiment: left: SEM image, middle: photo of the thin-section, right: 806 drawing indicating the main deformation structures. a) He/850/19 experiment showing two 807 sample-scale shear zones. b) He/900/21-32 experiment showing local shear zones and 808 boudinage of quartz - rich layer. Red lines associated to arrows: local shear zones. Black 809 arrows: the experimental compression direction. Dashed line rectangles: Locations for SEM 810 images from Fig. 7.

812 Figure 6: Shear zone orientations in experiments on the heterogeneous gneiss PX28. N: 813 number of shear zone used in the diagram. Mean: average orientation of shear zones. Colour 814 corresponds to the location of shear zone in regards to adjacent grains (e.g. quartz/quartz means that the shear zone is between quartz grains). $\sigma 1$ : experimental compression direction.

Figure 7: Grain-scale deformation in experiments on the heterogeneous gneiss PX28. a)

818 Biotite showing a sigmoid-like shape and broken biotites aligned along a plan representing a

819 shear zone. Location in Fig. 5a. b) Biotite and newly formed peritectic phase flow with glass 820 in quartz - rich layer at the location of boudinage (see Fig. 5b). d) Change in newly formed 821 peritectic phases orientation indicating flow of glass and peritectic phases. Fi: initial 822 orientation (corresponding to the foliation) of newly formed peritectic phases. c) Glass with 823 newly formed peritectic phase along cracks in plagioclase grains. All newly formed peritectic 824 phases are oriented parallel to crack walls. The light grey phase in contact between glass and 825 plagioclase is a K-rich phase, which may be due to reaction between glass and plagioclase.

826 Bt: biotite, Qtz: quartz, Gl: glass, Pl: plagioclase, Kfsp: K-feldspar. 
Figure 8: Grain - scale deformations in experiments on the homogeneous gneiss NOP1. a)

828 Kink bands in micas. Dashed lines: axial plan of kink bands. b) Empty cracks in quartz grain.

829 The curved crack along a glass filled crack is due to decompression. c) \& d) Glass filled

830 fracture network in quartz grains. c) White dashed lines: contours of glass filled fracture

831 network. Red dashed line: shear zone. d) Arrows: glass filed fracture network in quartz. e)

832 Glass filled injections. Dash lines highlight injections shape. Locations of b), c), d) and e) are 833 given in Fig. 4. Ms: muscovite. Bt: biotite, Gl: glass, Qtz: quartz, Pl: plagioclase.

Figure 9: a) Photomicrograph showing lobate grain boundaries along quartz grains in contact with glass $(\mathrm{Gl})$. b) SEM image showing lobate boundaries along quartz grains in contact with glass. c) Photomicrograph and related schematic drawing (d) showing melt distribution along quartz grain boundaries and intergranular displacements of quartz grains with respect to each other. This might argue for melt assisted granular flow.

Figure 10: Glass distribution in experiments on the homogeneous gneiss NOP1. Glass is represented in black in the drawings. The rose-diagrams represent glass film or pocket orientations. Dark grey population: glass films and pockets perpendicularly oriented to the experimental compression direction (black arrows). Light grey: orientation population corresponding to glass injection. The second population in a) corresponds to melt films and 846 pockets with an oblique orientation to the experimental compression direction. Dashed red lines in b): shear zones (corresponding to the ones in Fig. 8d) showing no increase in melt content at their vicinity.

850 Figure 11: Local glass distribution in Ho/850/33. a) Location of b, c, and d in Ho/850/33 core. 851 Location of Fig. 10b is also reported. Thick black dashed lines: shear zones defined from Fig. 
4b. b) Glass associated to micas. White arrows: glass films along muscovite - quartz boundaries often associated with newly formed peritectic phases (blue). Glass with newly formed peritectic phases is only found close to micas. Black arrows: glass always associated to newly formed peritectic phases along mica cleavage. c) Glass filled crack (white arrow) parallel to the experimental compression direction (black arrows) in quartz grain. Thin dashed black lines mark the shape of the crack. Thick oblique dashed lines: shear zones defined from Fig. 4b. Glass in not particularly accumulates at the vicinity of shear zones. d) Glass filled cracks free of newly formed phase in quartz supported network.

Glass estimates correspond to blue and red colours. $\varphi$ : newly formed peritectic phases. Thick vertical black arrows: experimental compression direction. Bt: biotite, Ms: muscovite, Gl: glass, Kfs: K-feldspar, Pl: plagioclase, Qtz: quartz. Other: accessory minerals and K-rich phase in contact between plagioclase and melt.

Figure 12: Glass distribution in experiments on the heterogeneous gneiss PX28. Glass is represented in black in the drawings. The rose-diagrams represent glass film or pocket orientations. a) Greater glass amount in mica - rich layer than in quartz - rich layer. Glass films and pockets oriented perpendicularly to the experimental compression direction (black arrows) in mica - rich layer and parallel to the experimental compression direction in quartz rich layer. b) High variability of glass amount at sample scale and between mica - rich and quartz - rich layers. Black arrows=experimental compression direction.

Figure 13: Local glass distribution in He/900/21-32. a) Location of the different areas illustrated in b), c) and d). b) Great glass amount associated with newly formed peritectic phases and small biotites in an inter-boudin position (defined in Fig. 5b). Green dashed lines in a) and b) correspond to the boundary of inter-boudin area as defined in Fig. 5b. c) Glass 
877 veins, free of newly formed phase, in quartz grain (white arrow). Glass is also present within 878 plagioclase grain. d) Glass films, free of newly formed peritectic phase, at quartz 879 plagioclase boundaries.

880 Glass estimates correspond to blue and red colours. $\varphi$ : newly formed peritectic phases. Other: 881 accessory minerals and K-rich phase in contact between plagioclase and melt. Bt: biotite, Ms: 882 muscovite, Gl: glass, Kfs: K-feldspar, Pl: plagioclase, Qtz: quartz.

884 Figure 14: a) Outcrop photograph showing a metatexite where the onset of partial melting is marked by ca. $20 \mathrm{~cm}$ long lense-shaped leucosomes that lie parallel to the planar fabrics of the protolith, Fuping complex (North China Craton). b) Stromatic metatexite of paragneiss where boudinage of quartz-rich competent layers led to melt migration toward boudin-neck (white arrows), southern Velay dome (French Massif Central, France).c) Stromatic migmatite with a set of leucosomes that parallels the gneissic layering and a second set of leucosomes located in shear zones. Melt migrates toward shear zones, Archean Snowbird tectonic zone (Canada, courtesy from Philippe Goncalves).

\section{Table caption}

894 Table 1: Experimental conditions used in deformation experiments and parameters derived 895 from the experiments. PP123 is a hydrostatic experiment. Experiment names are built on the 896 following schema: "type of material/temperature $\left({ }^{\circ} \mathrm{C}\right) /$ melt content (surfacic percentage)". 897 "Ho" means homogeneous gneiss and "He" means heterogeneous gneiss. In the particular 898 case of $\mathrm{He} / 900 / 21-32$, it is not possible to define a meaningful mean main content as melt 899 content varies a lot through the sample (see Fig. 12). Thus we use both estimates made in two 900 different zones (see part 4.5). 

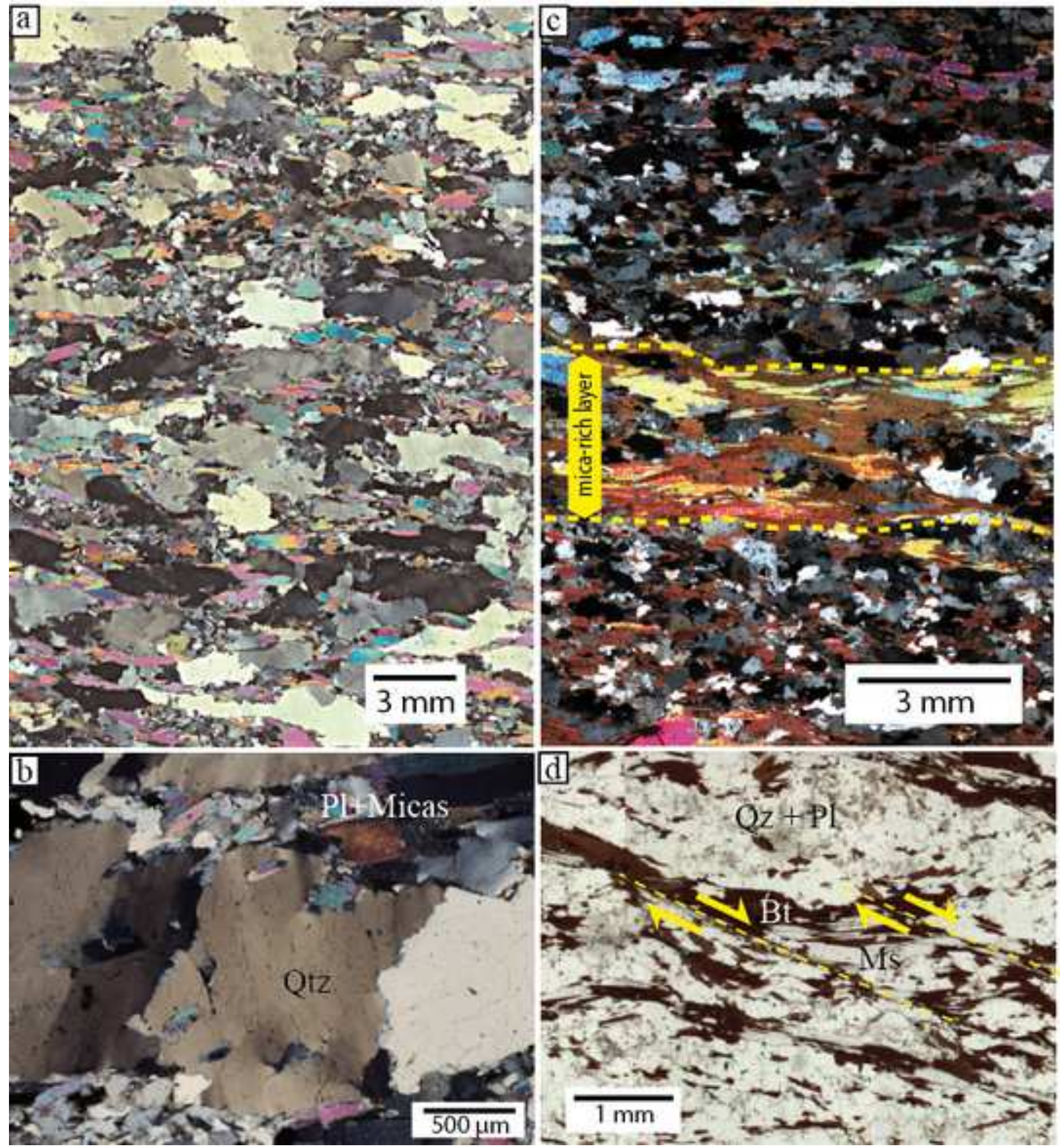
Click here to download high resolution image

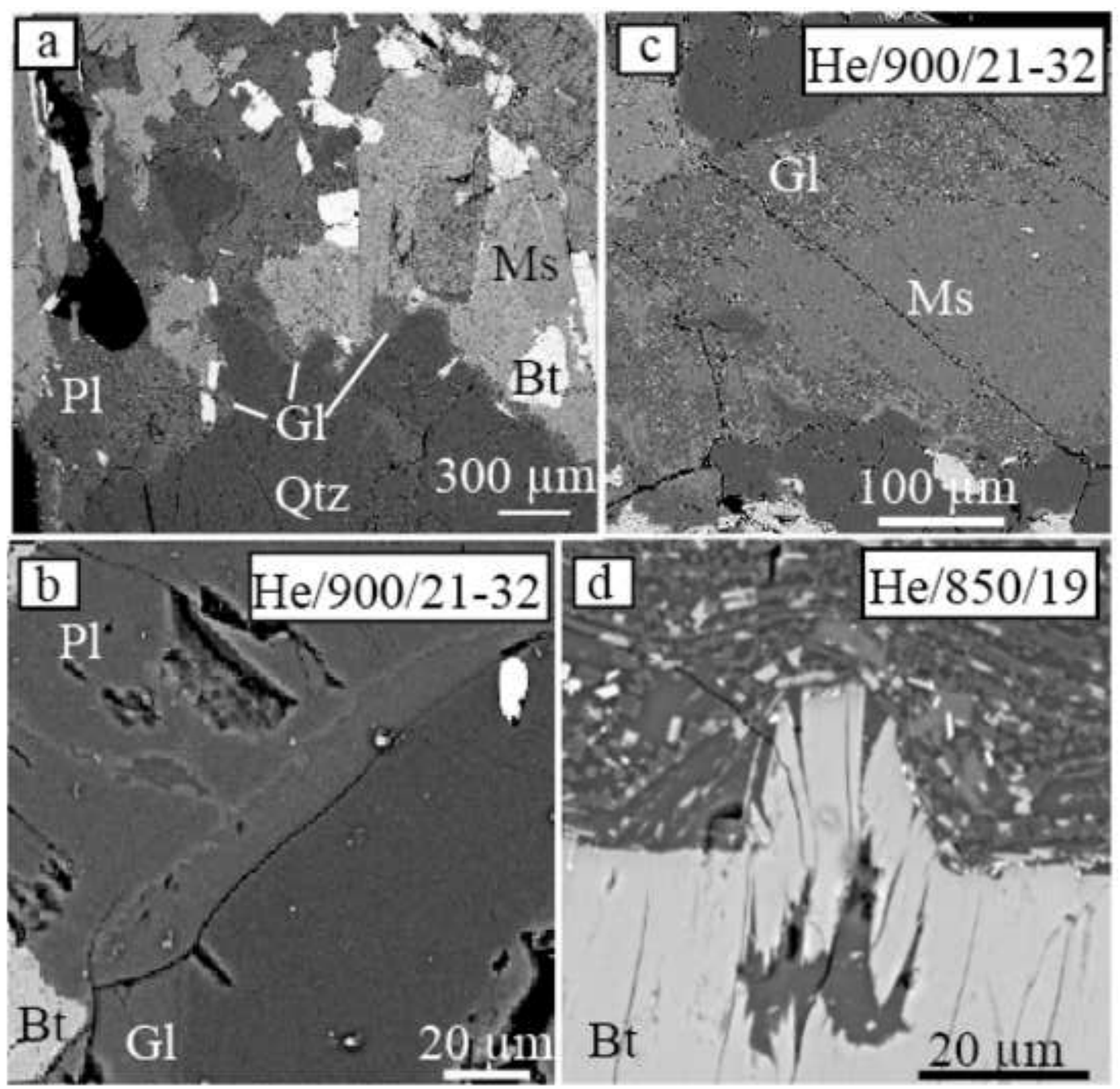




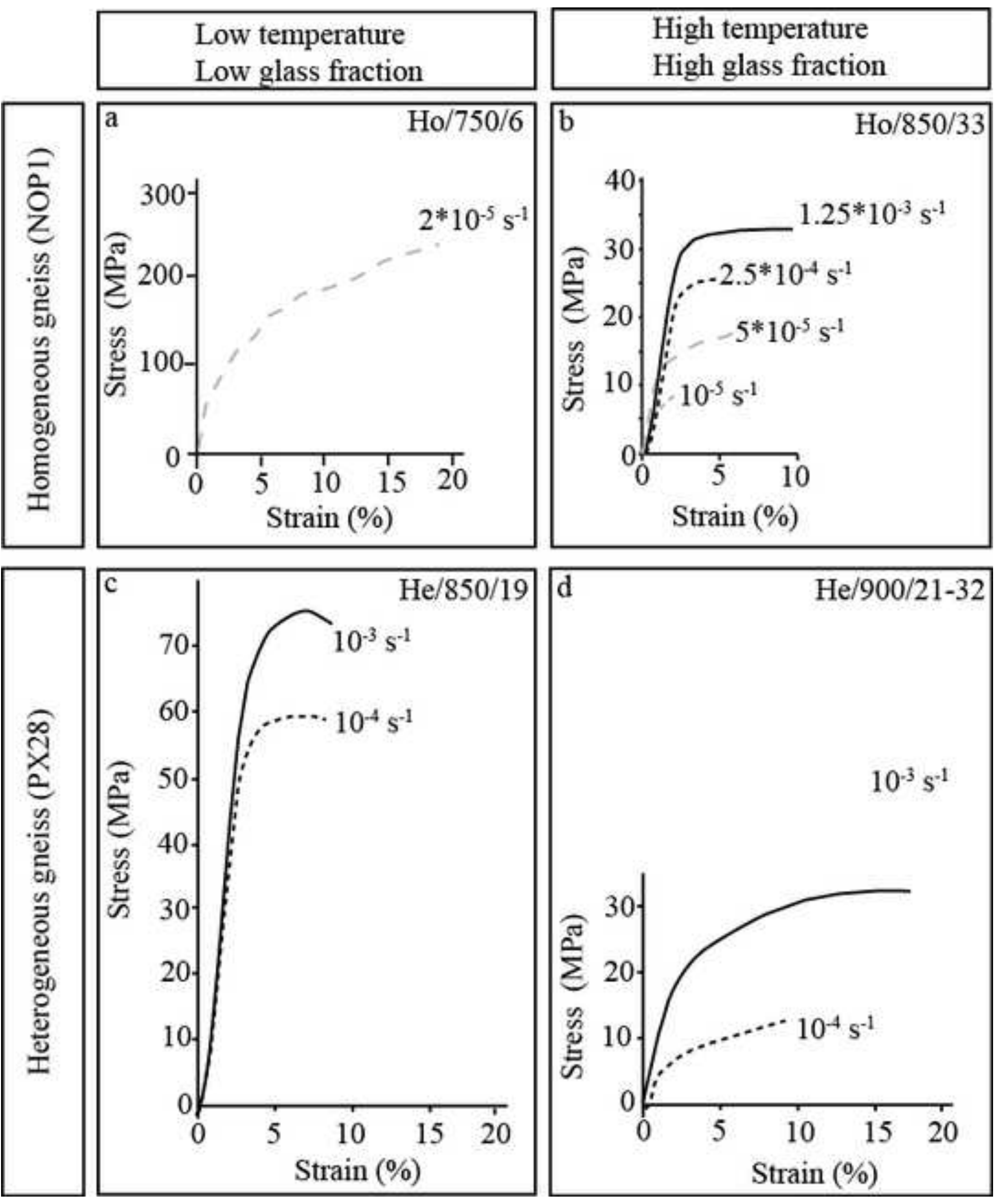




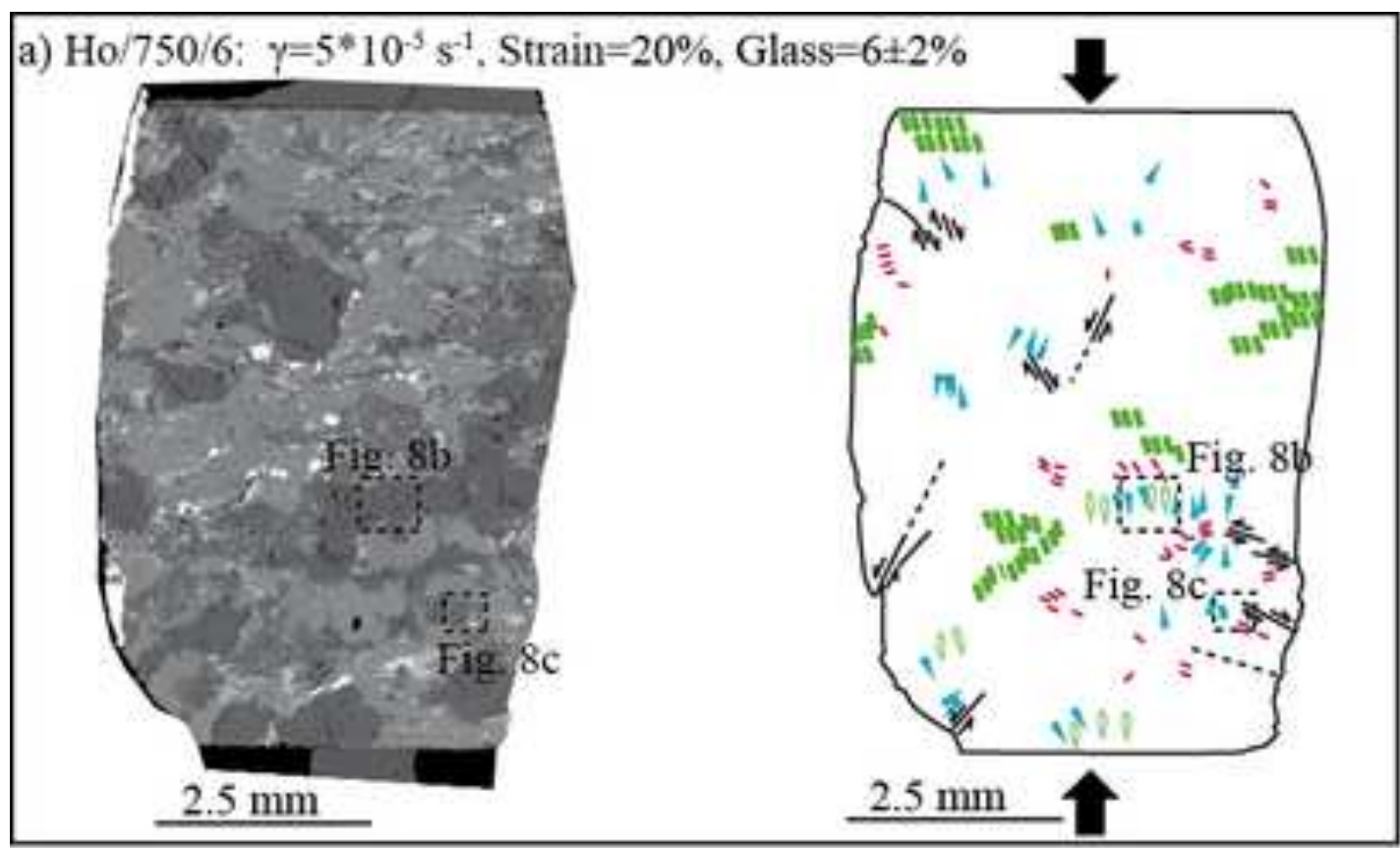

\begin{tabular}{|l|}
\hline i. \\
melt free cracks \\
, kink band axis \\
wcrystal breackage \\
shear zone
\end{tabular}

b) $\mathrm{Ho} / 850 / 33: \gamma=10^{-5}-1.25^{*} 10^{-3} \mathrm{~s}^{-1}$, Strain $=11 \%$, Glass $=33 \pm 4 \%$
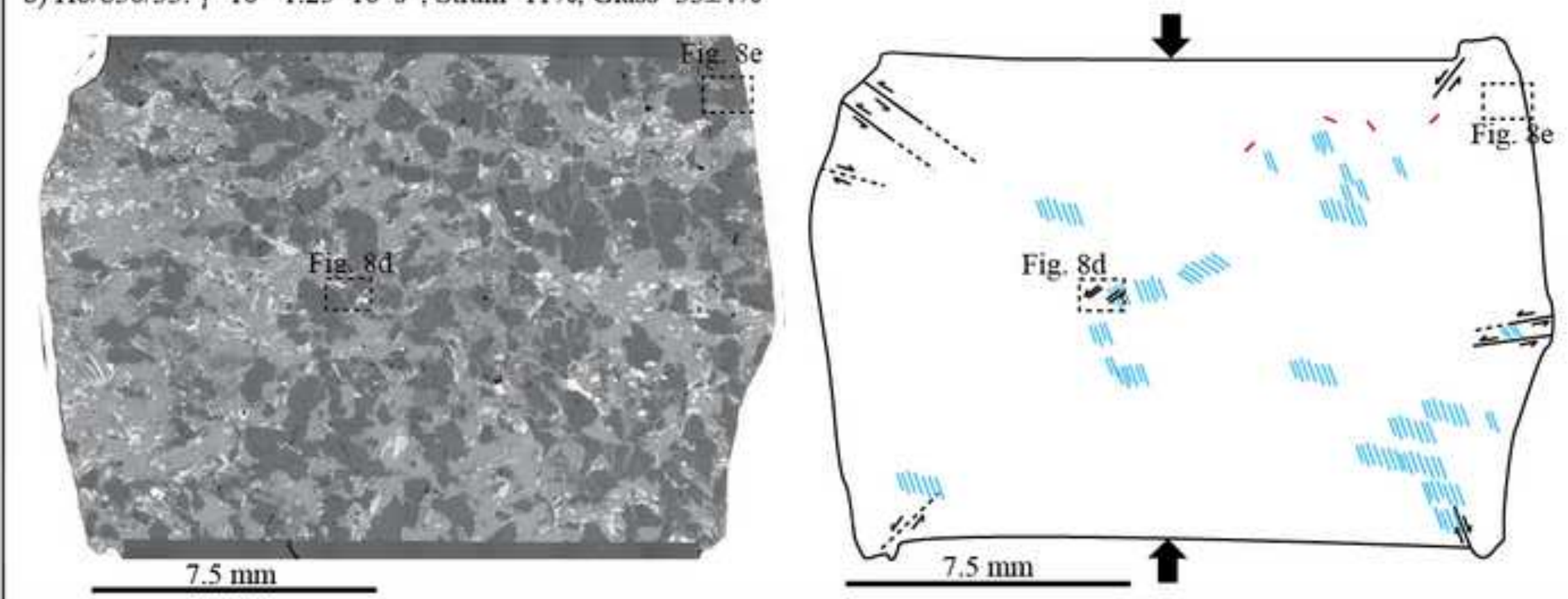
a) $\mathrm{He} / 850 / 19: \gamma=10^{-4}-10^{-3} \mathrm{~s}^{-1}$, Strain $=20 \%$, Glass $=19.2 \pm 5.7 \%$
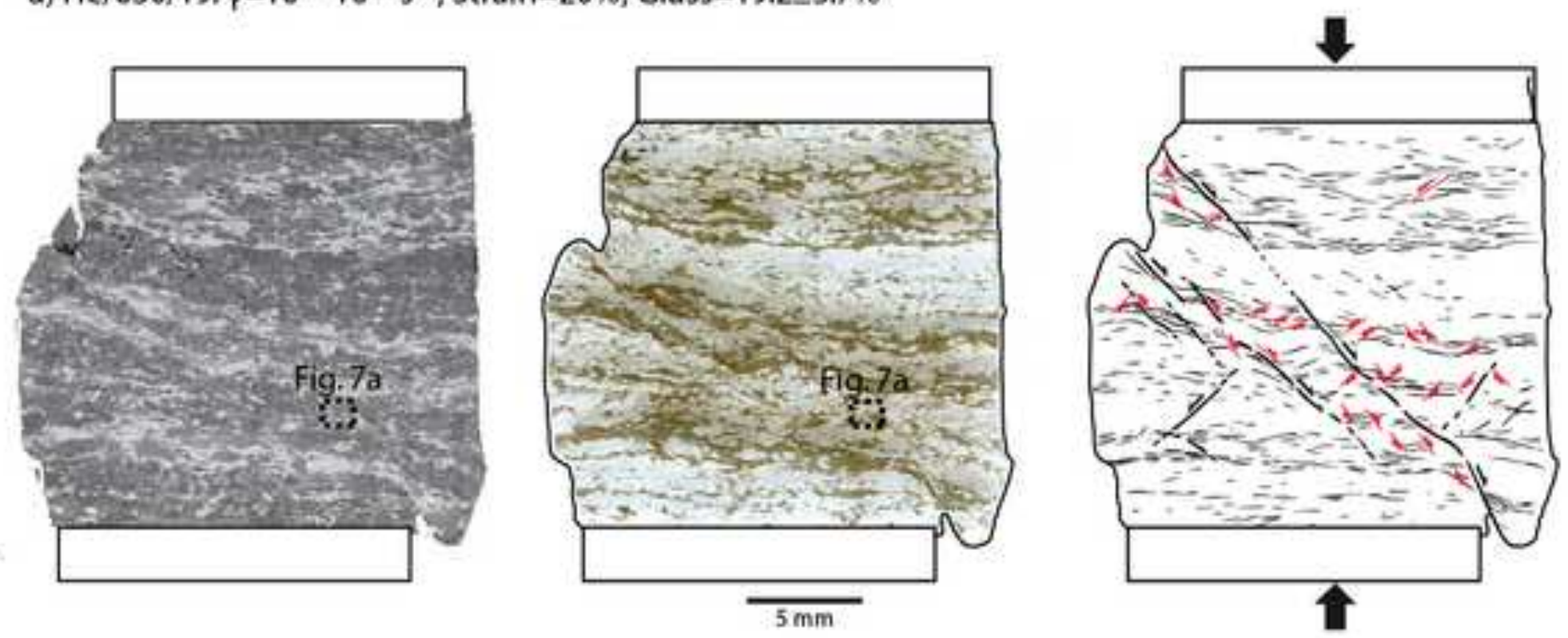

b) $\mathrm{He} / 900 / 21-32: y=10^{-4}-10^{-3} \mathrm{~s}^{-1}$, Strain $=27 \%$, Glass $=21 \pm 7-32 \pm 6 \%$
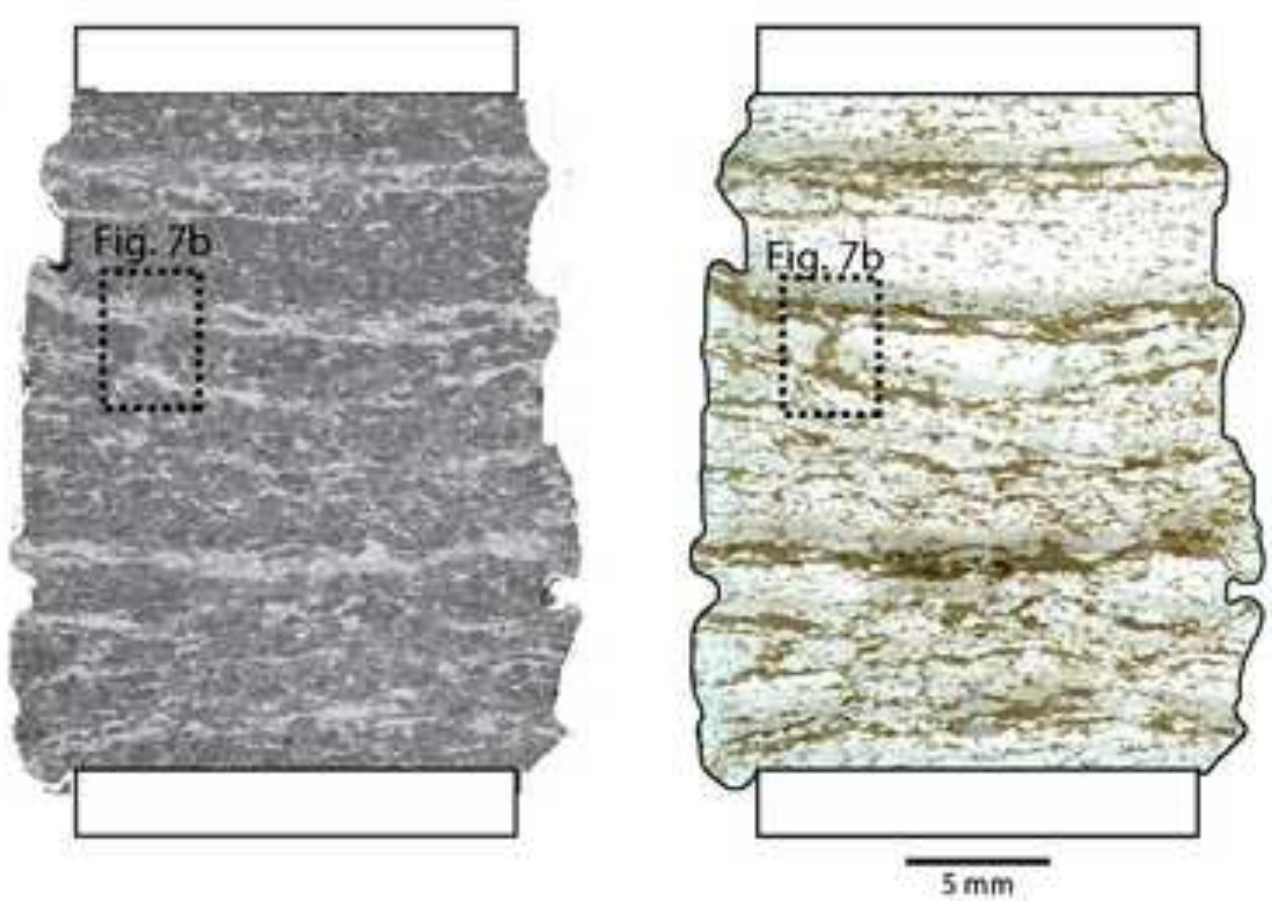
Boudinage of the
quartz-rich layer

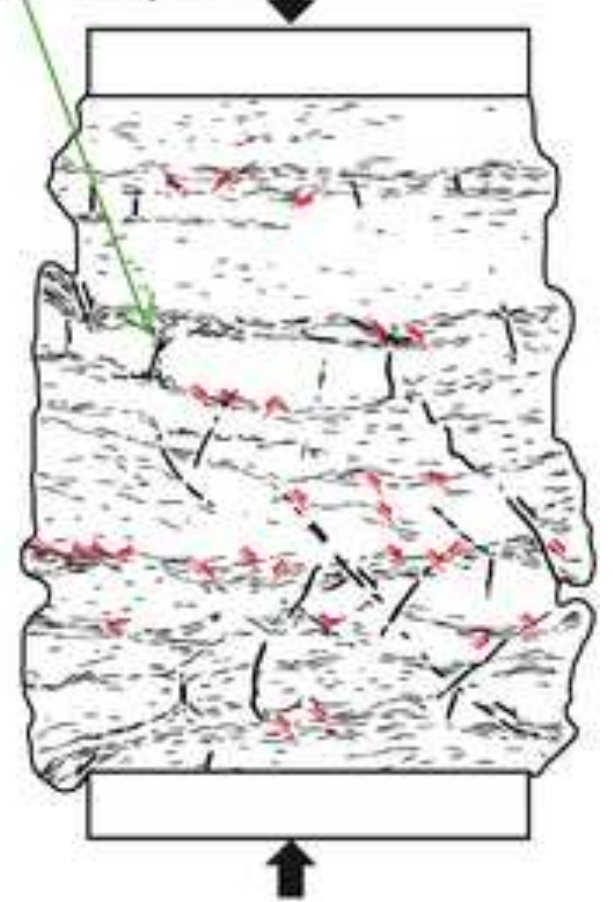




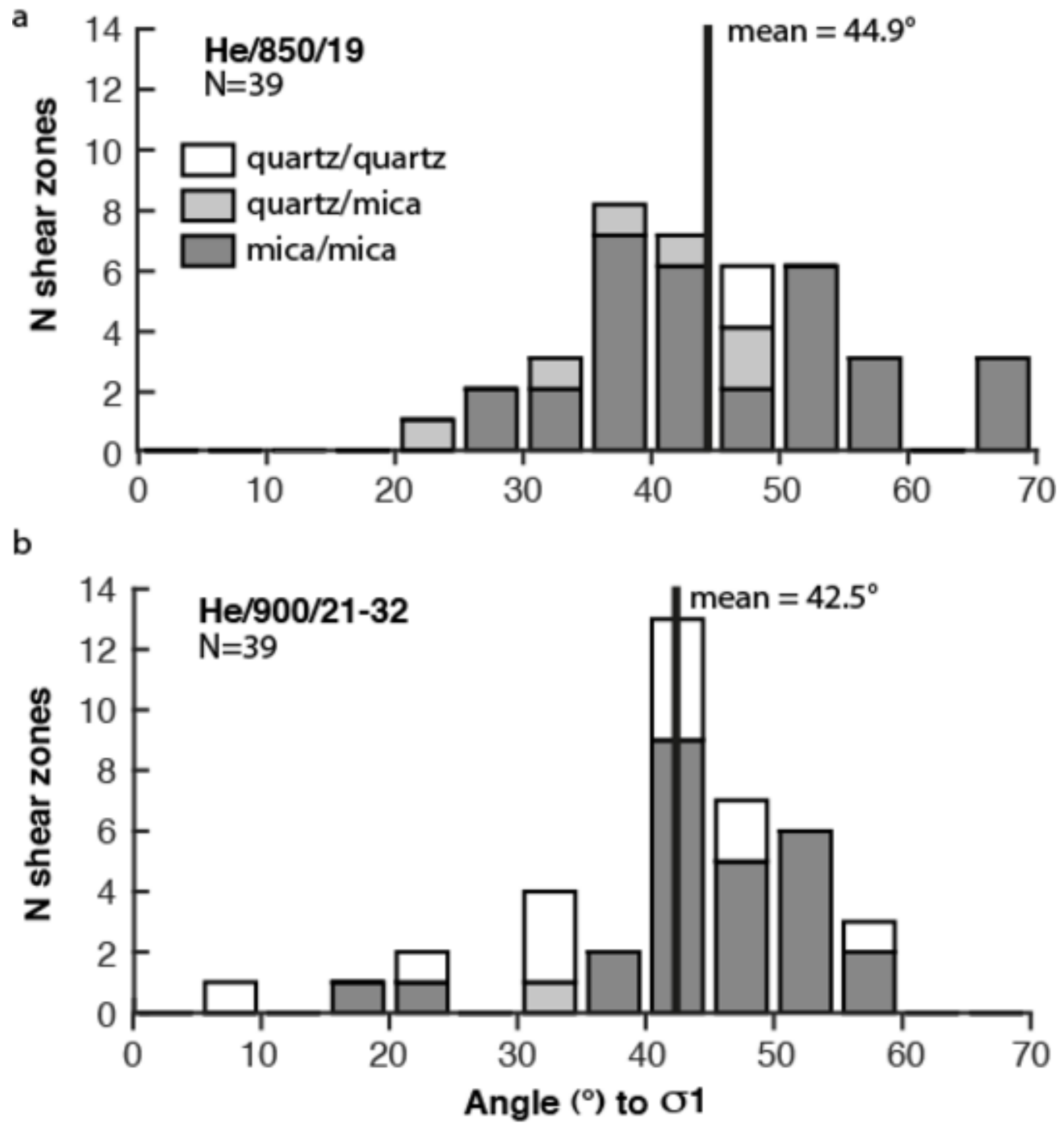




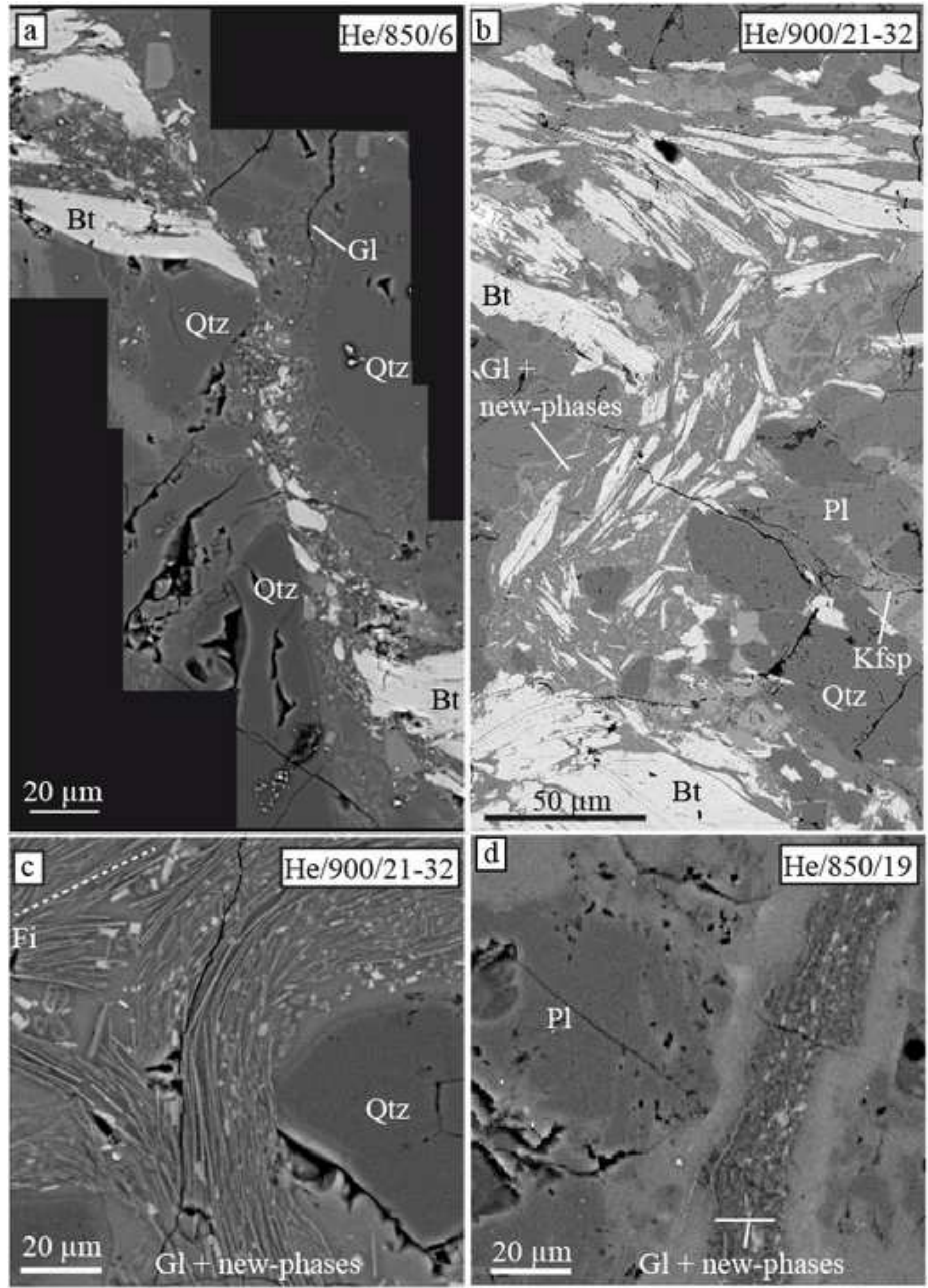



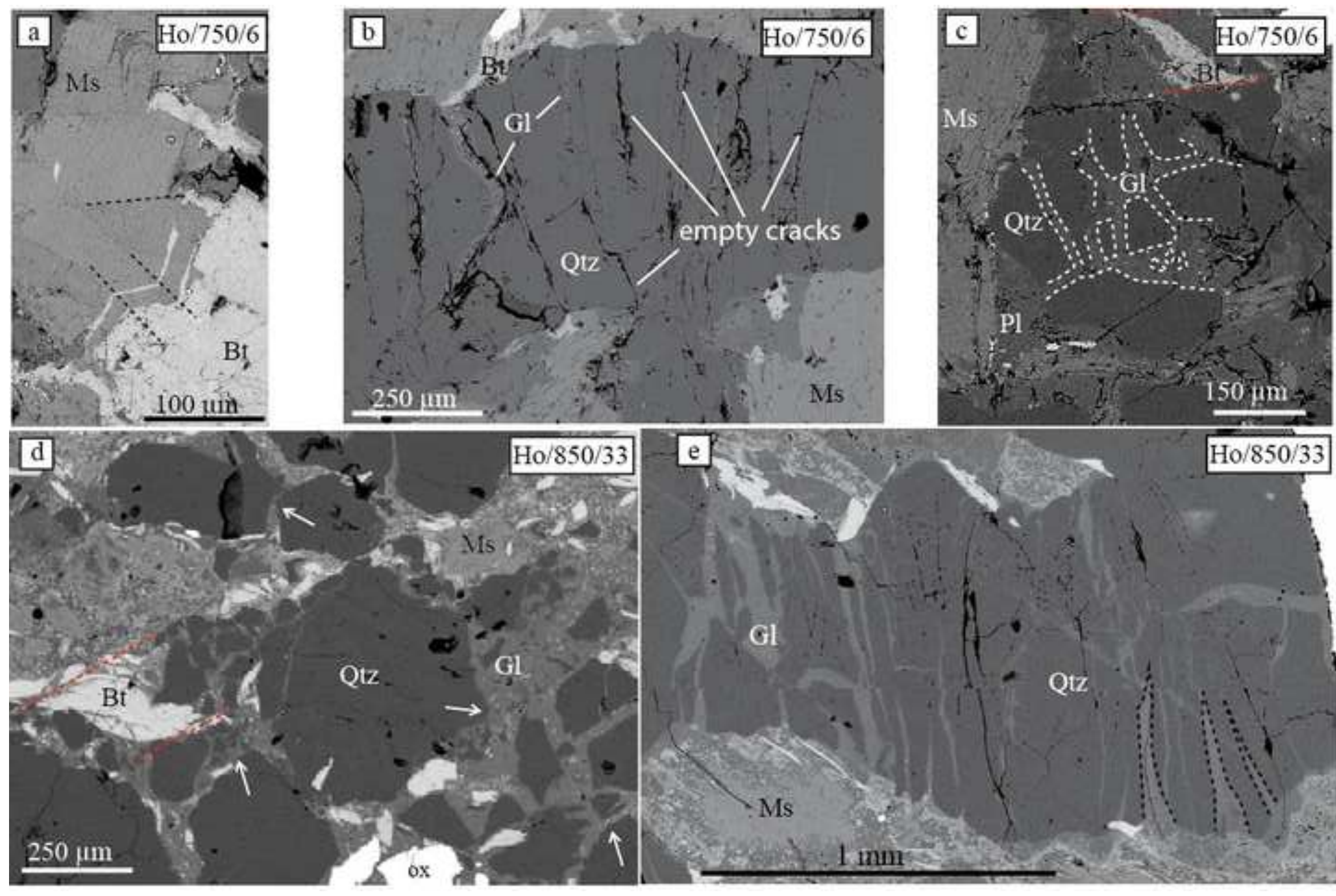

$\mathrm{Ho} / 850 / 33$

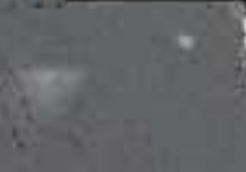



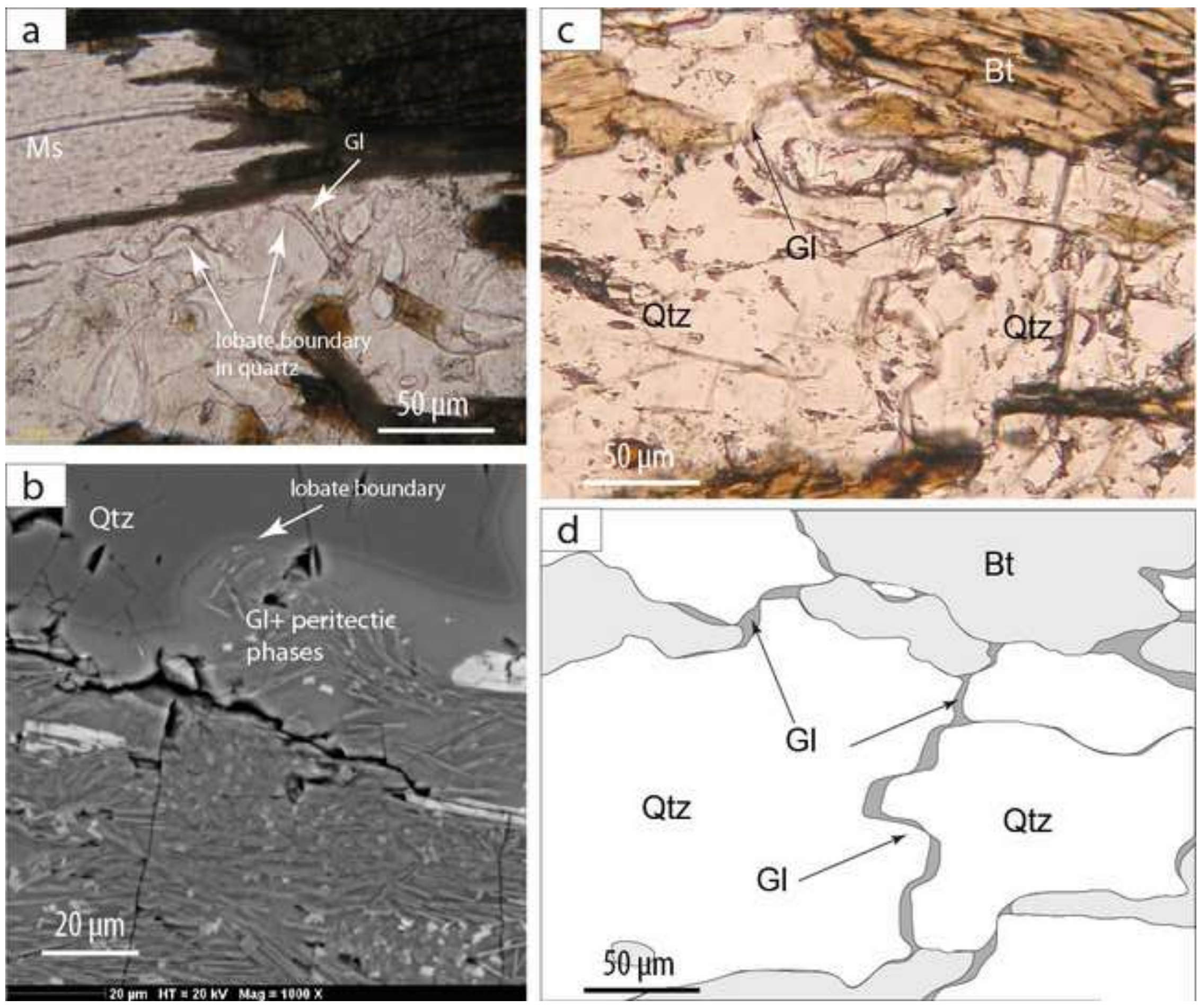

.5010 in
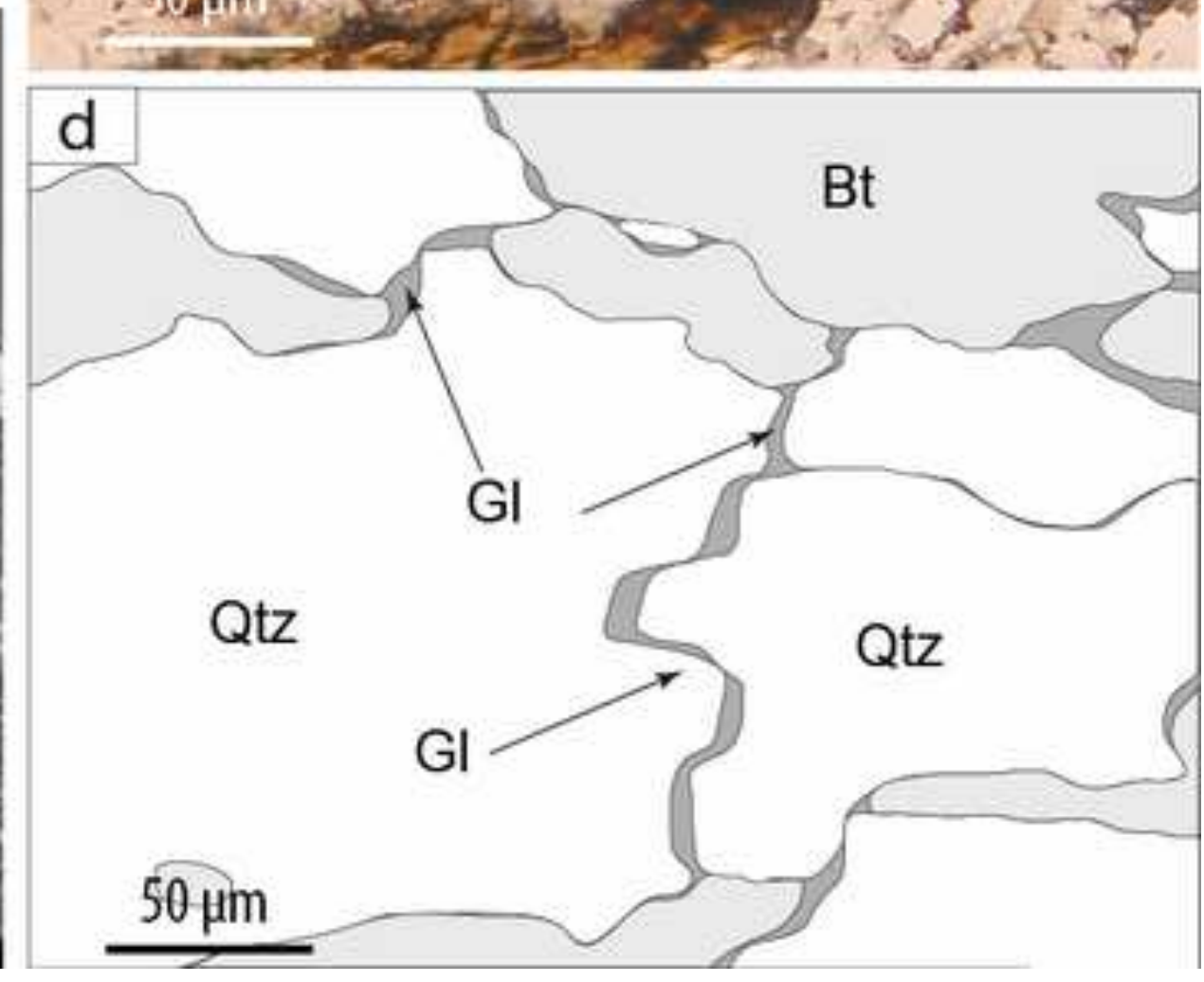


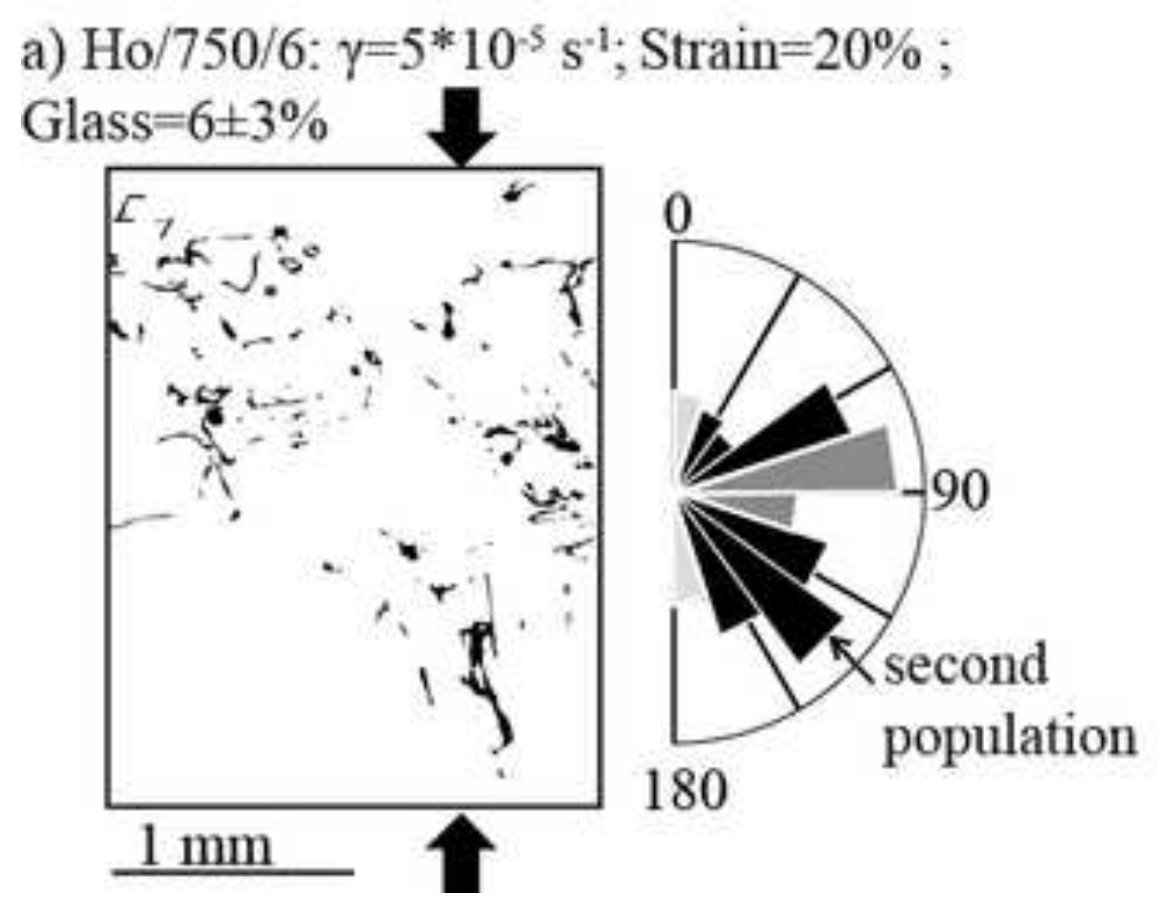

b) Ho/850/33: $\gamma=10^{-5}-1.25^{*} 10^{-3} \mathrm{~s}^{-1} ; \mathrm{Strain}=11 \%$; Glass $=33 \pm 4 \%$

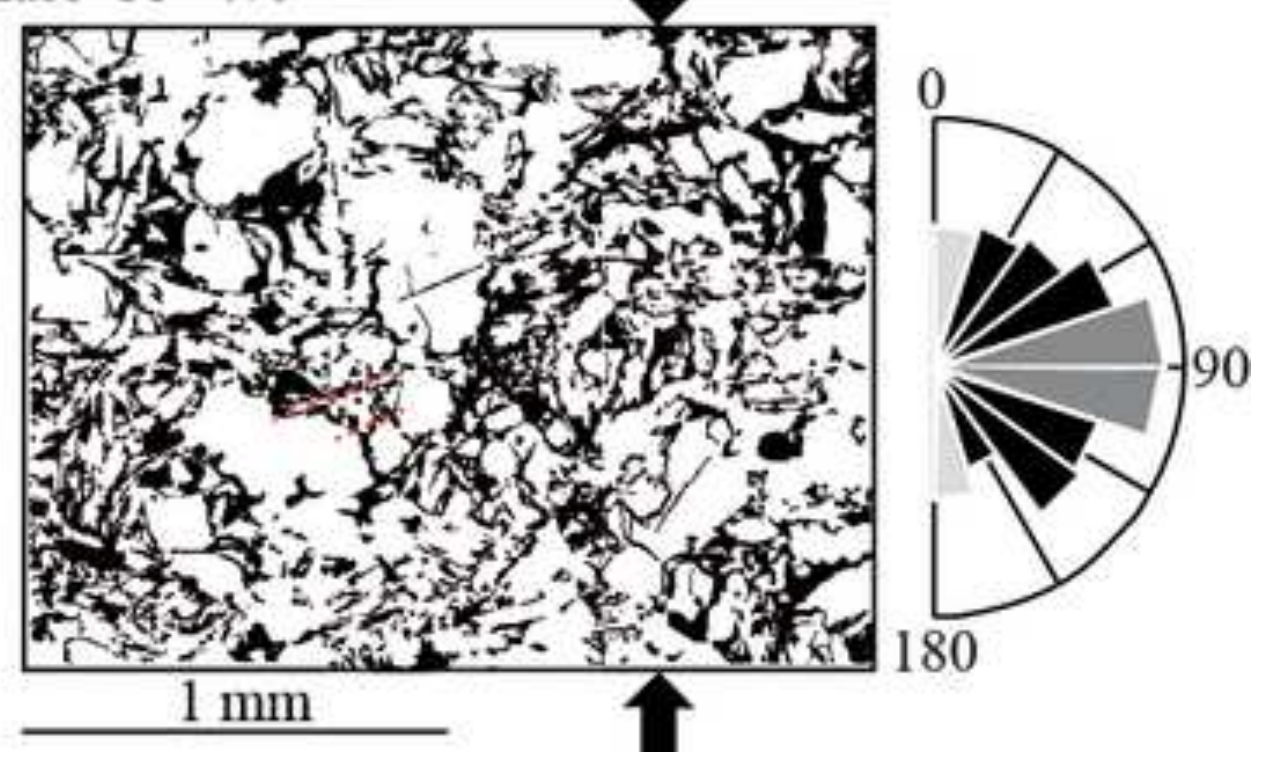



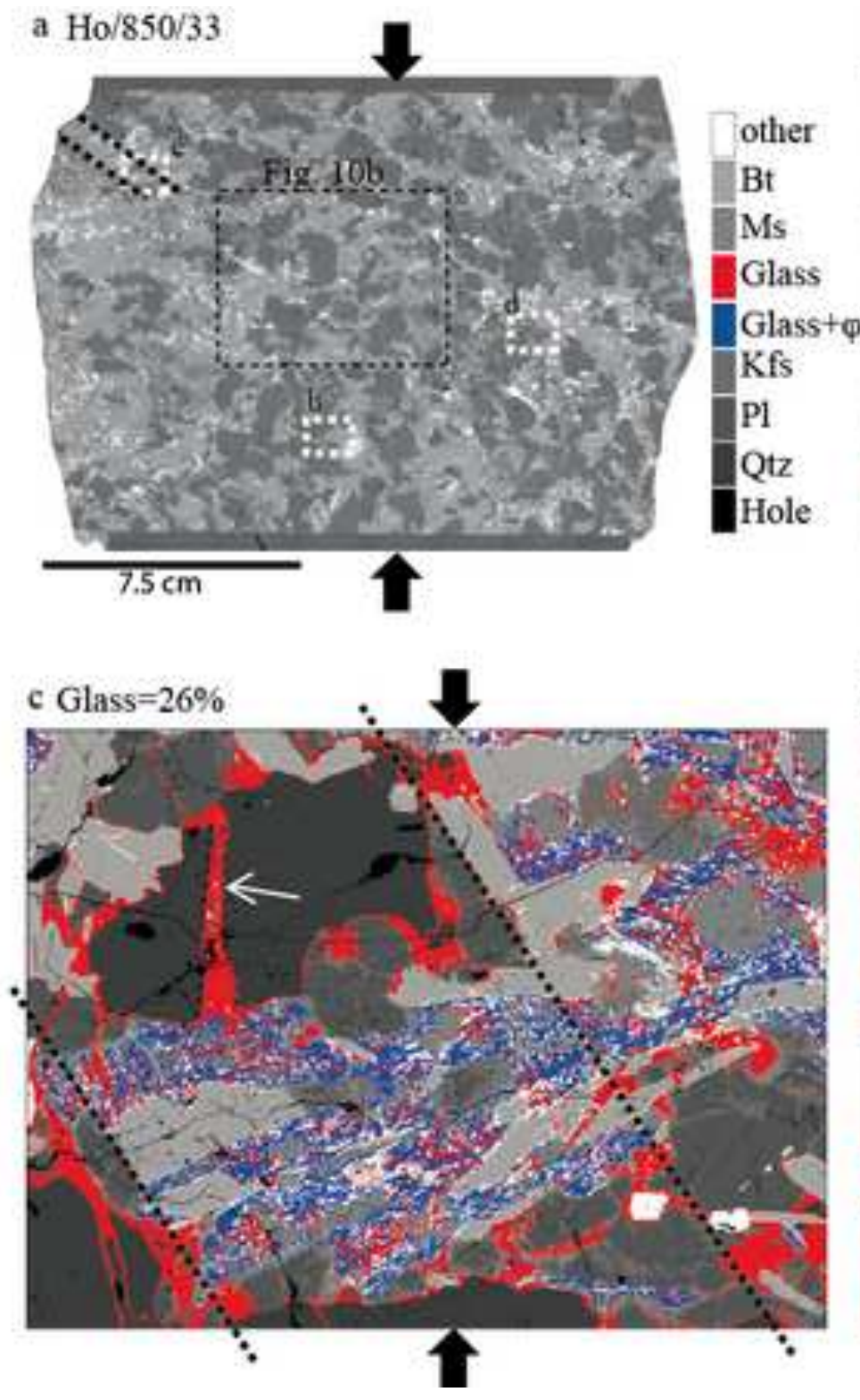

b Glass $=20 \%$

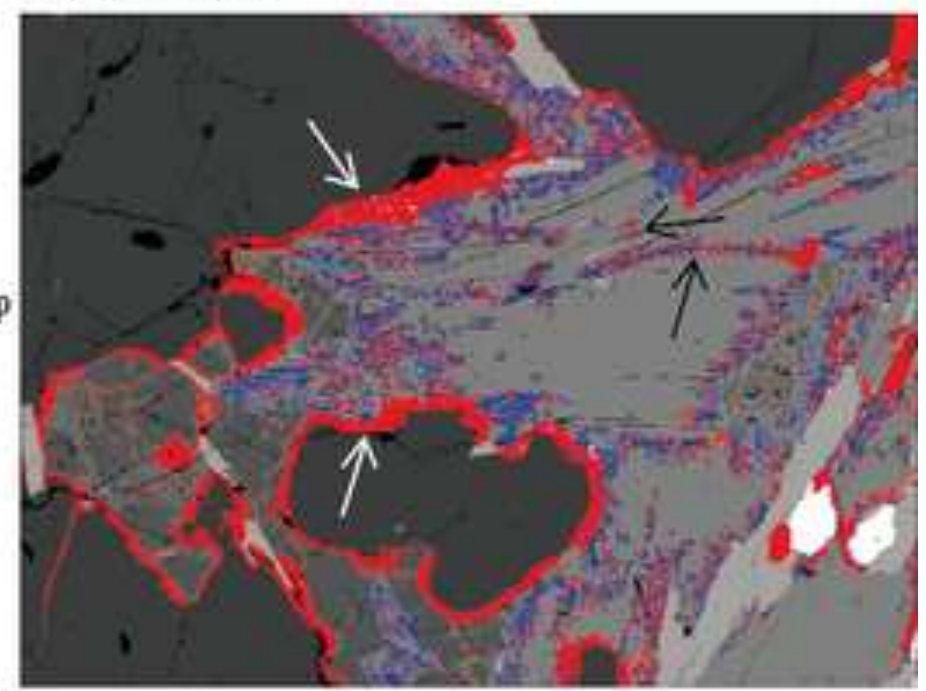

d Glass $=50 \%$

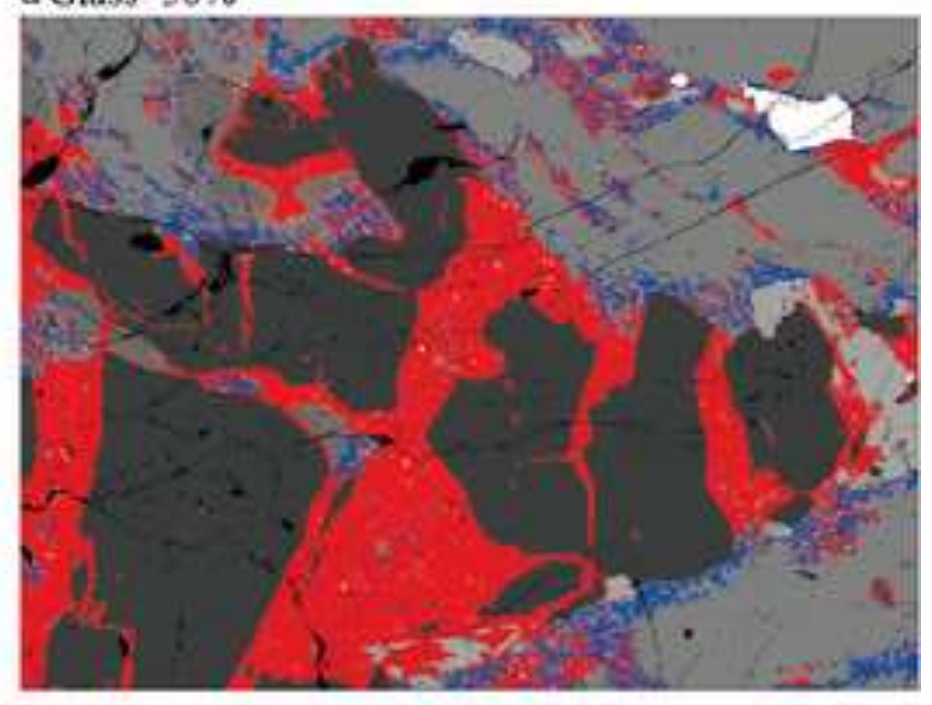


Click here to download high resolution image

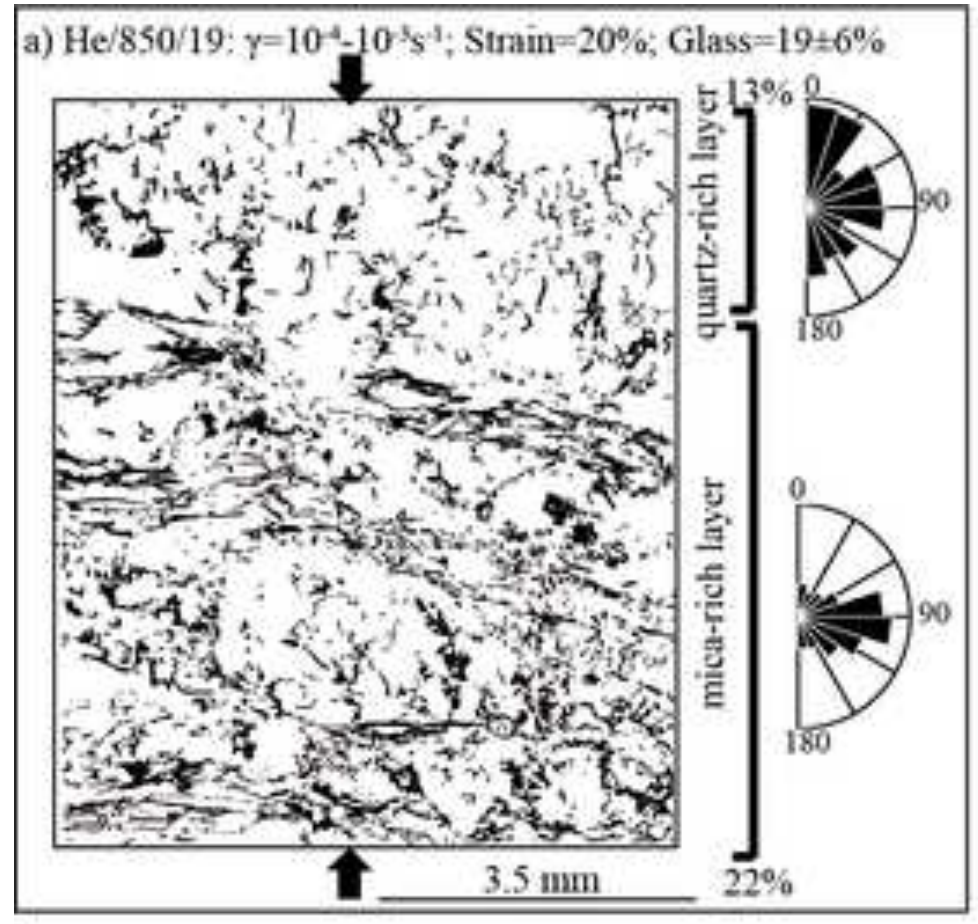

b) $\mathrm{He} / 900 / 21-32: \gamma=10^{-4}-10^{-3} \mathrm{~s}^{-4} ;$ Strain $=20 \%$
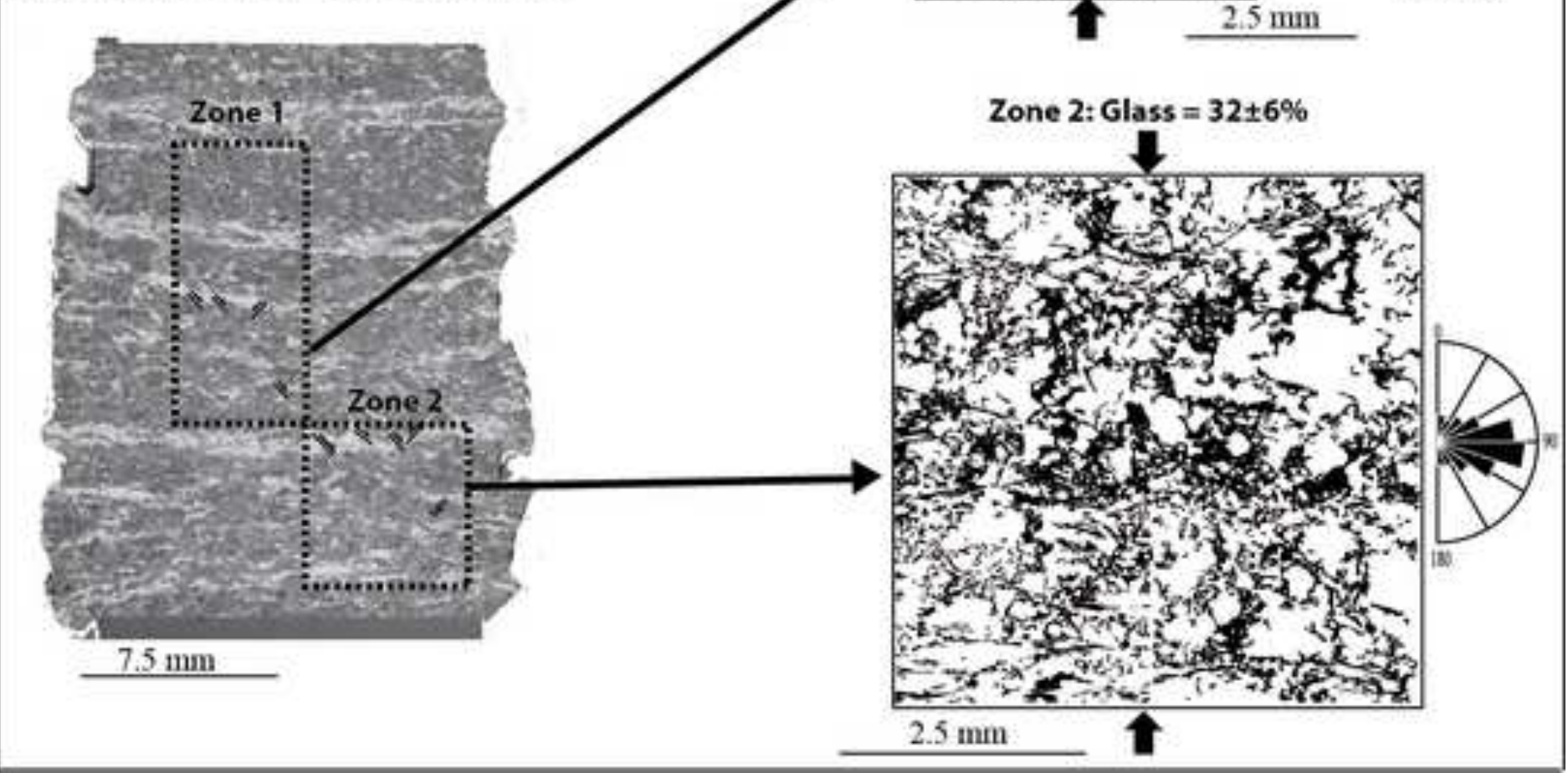
a $\mathrm{He} / 900 / 21-32$

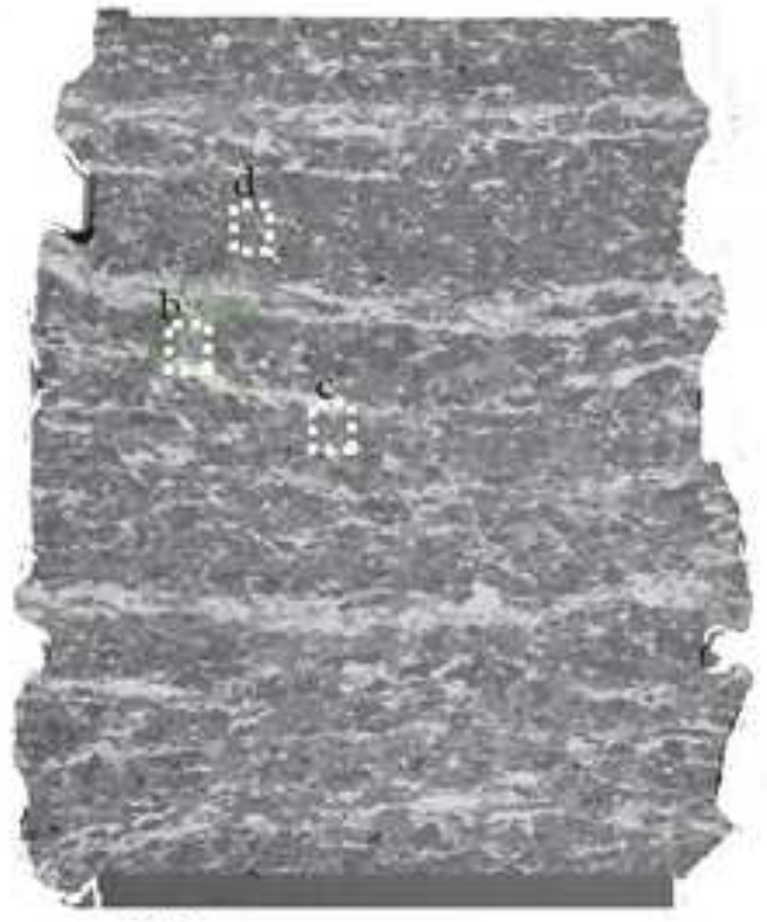

\section{$7.5 \mathrm{~cm}$}

c Melt $=20 \%$

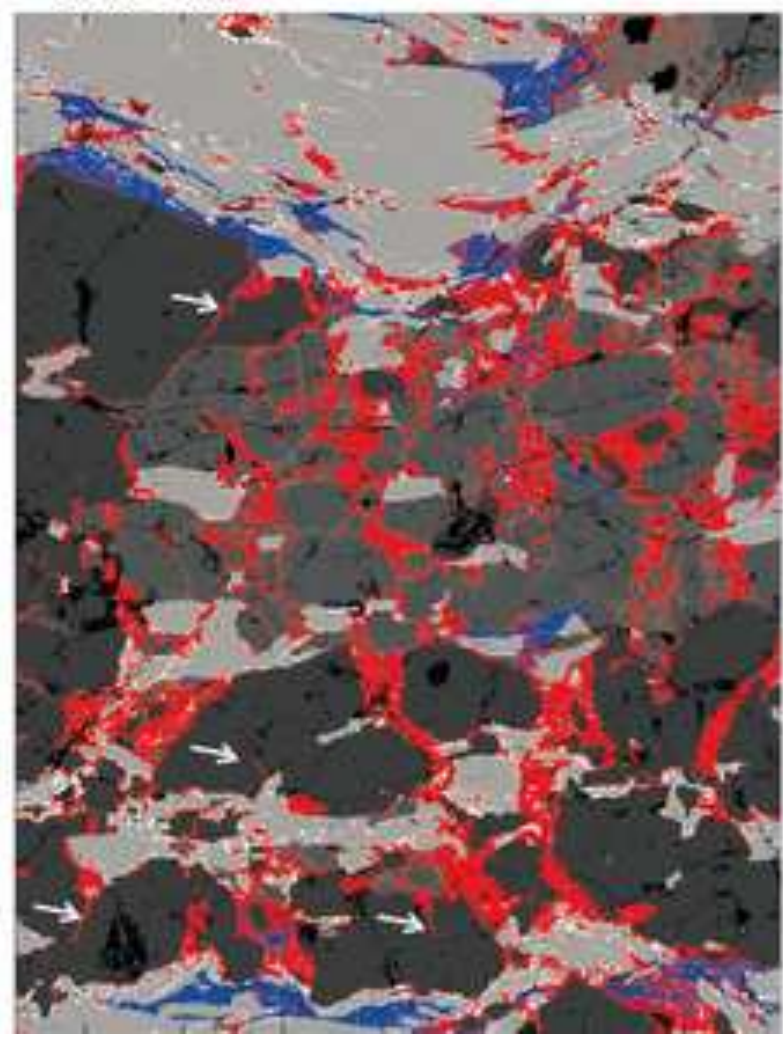

b Melt $=41 \%$ -

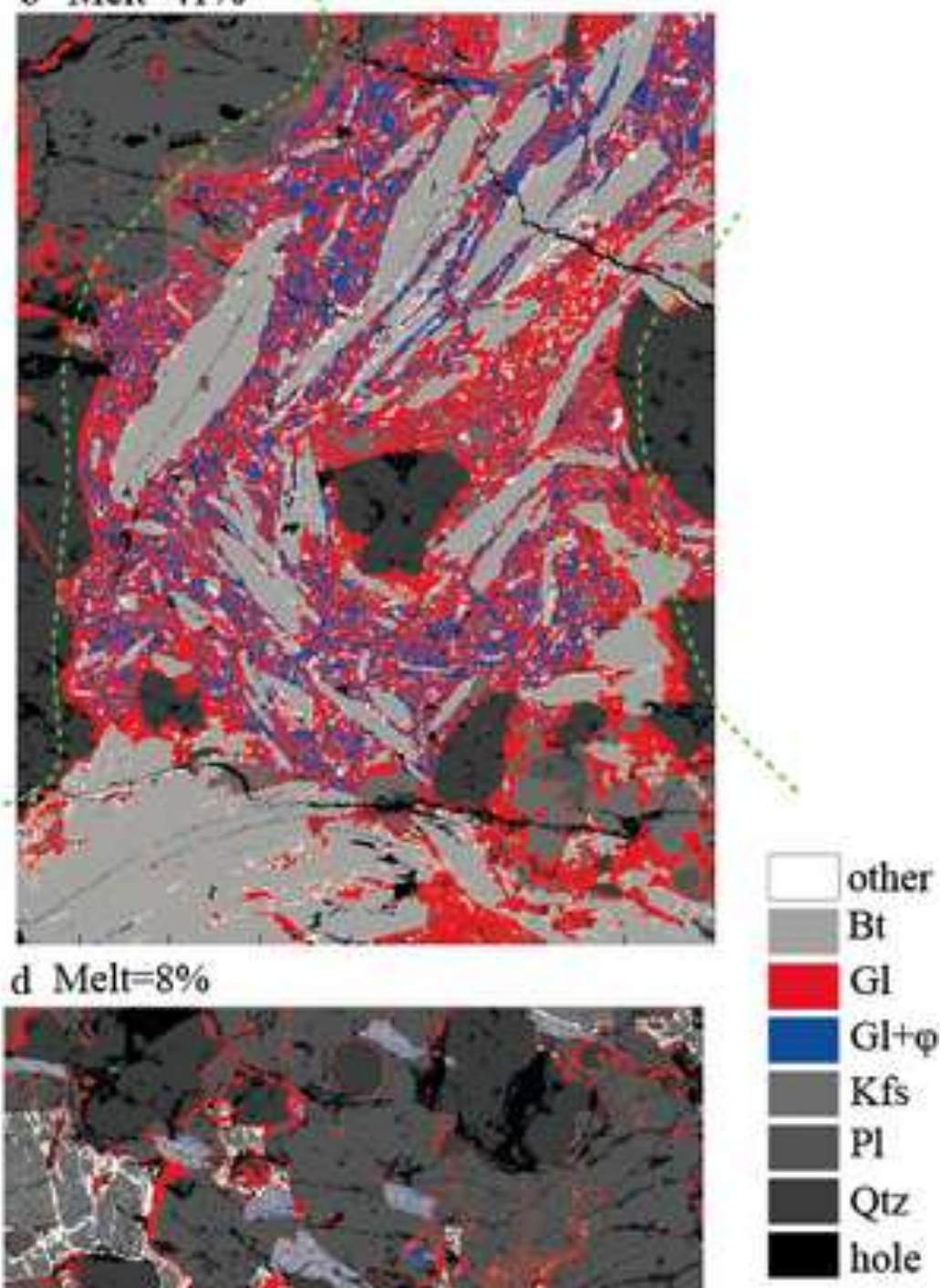


Click here to download high resolution image
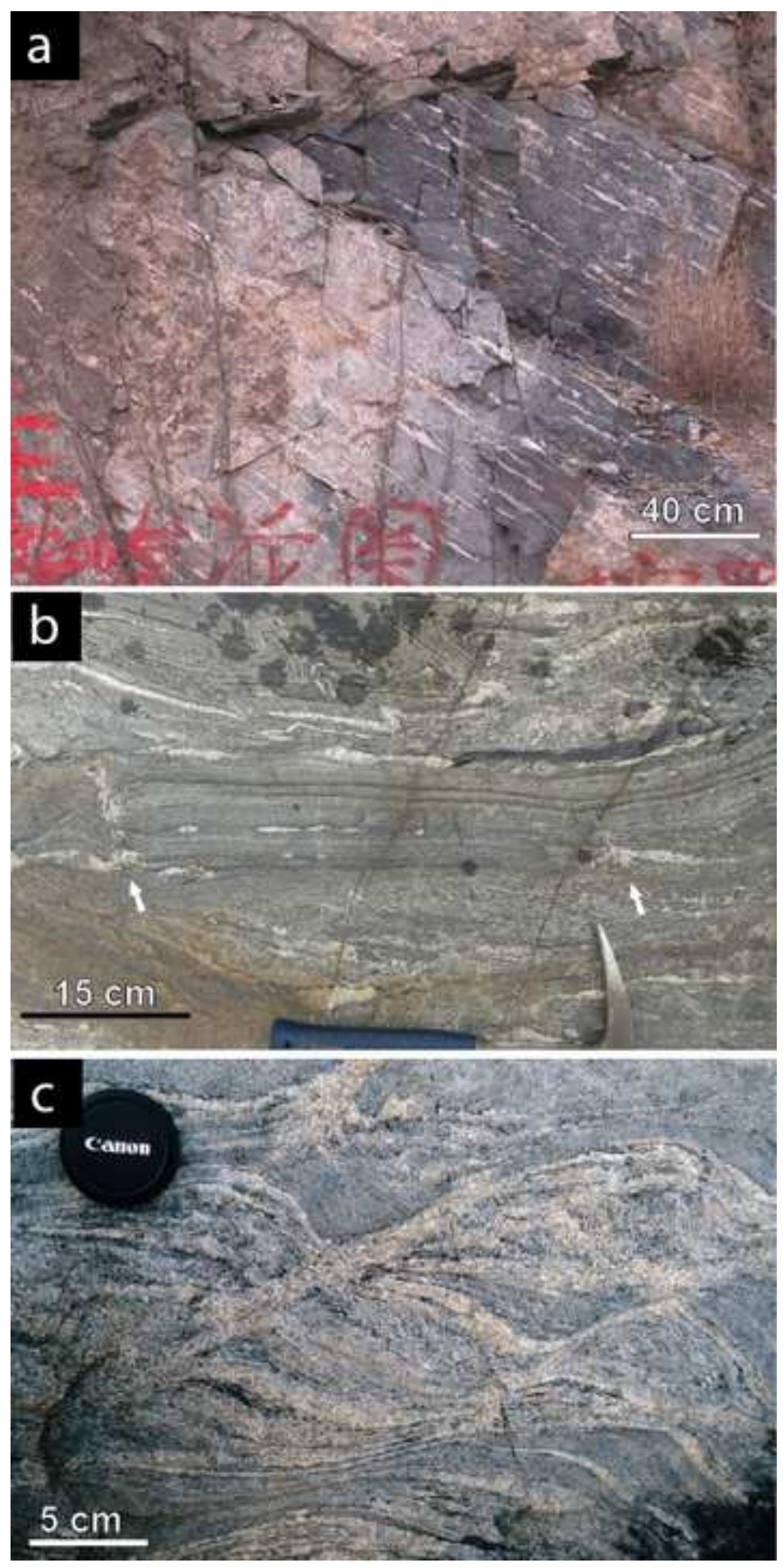


\begin{tabular}{|c|c|c|c|c|c|c|c|c|c|c|}
\hline $\begin{array}{c}\text { experiment } \\
\text { name }\end{array}$ & \multirow{2}{*}{$\begin{array}{l}\text { experiment } \\
\text { number }\end{array}$} & \multirow[t]{2}{*}{$\begin{array}{c}\text { starting } \\
\text { material } \\
\end{array}$} & jacket & \multicolumn{2}{|c|}{$\begin{array}{c}\text { size } \\
\text { diameter }(\mathrm{mm} \text { length }(\mathrm{mm})\end{array}$} & \multirow[t]{2}{*}{$\begin{array}{c}\mathrm{T} \\
\left({ }^{\circ} \mathrm{C}\right) \\
\end{array}$} & \multirow[t]{2}{*}{$\begin{array}{c}\text { Strain rate } \\
\left(\mathrm{s}^{-1}\right)\end{array}$} & \multirow[t]{2}{*}{$\begin{array}{c}\text { duration } \\
\text { (hour) }\end{array}$} & \multirow[t]{2}{*}{$\begin{array}{c}\text { Strain } \\
(\%) \\
\end{array}$} & \multirow[t]{2}{*}{$\begin{array}{c}\text { melt content } \\
(\%)\end{array}$} \\
\hline \multicolumn{4}{|c|}{ Protolith: NOP1 (Homogeneous) } & & & & & & & \\
\hline \multirow[t]{4}{*}{$\mathrm{Ho} / 850 / 33$} & PP218 & NOP1-A & $\mathrm{Fe}+\mathrm{Pt}$ & 15 & 15.19 & 850 & $10^{-5}$ & 0.6 & 2.1 & \\
\hline & & & & & & & $5 * 10^{-5}$ & 0.3 & 3 & \\
\hline & & & & & & & $2.5 * 10^{-4}$ & 0.06 & 3 & \\
\hline & & & & & & & $1.25 * 10^{-3}$ & 0.02 & 3 & 33 \\
\hline $\mathrm{Ho} / 750 / 6$ & PP315 & NOP1-B & $\mathrm{Fe}+\mathrm{Cu}$ & 5 & 10.29 & 750 & $2 * 10^{-5}$ & 2.87 & 20 & 6 \\
\hline \multicolumn{11}{|c|}{ Protolith: PX28 (Heterogeneous) } \\
\hline - & PP123 & - & $\mathrm{Fe}+\mathrm{Pt}$ & 14.91 & 19.42 & 850 & 0.0 & 1.75 & 0 & unknown \\
\hline \multirow[t]{2}{*}{$\mathrm{He} / 900 / 21-32$} & PP111 & - & $\mathrm{Fe}+\mathrm{Pt}$ & 15 & 28.8 & 900 & $10^{-4}$ & 0.28 & 10 & \\
\hline & & & & & & & $10^{-3}$ & 0.05 & 17 & $21-32$ \\
\hline \multirow[t]{2}{*}{$\mathrm{He} / 850 / 19$} & PP113 & - & $\mathrm{Fe}+\mathrm{Pt}$ & 15 & 21.74 & 850 & $10^{-1}$ & 0.23 & 8.4 & \\
\hline & & & & & & & $10^{-3}$ & 0.02 & 8.8 & 19 \\
\hline
\end{tabular}

